Article

\title{
Exploring the Research Regarding Frugal Innovation and Business Sustainability through Bibliometric Analysis
}

\author{
Adriana Dima ${ }^{1, *(\mathbb{D}}$, Alexandru-Mihai Bugheanu ${ }^{1}$, Ruxandra Dinulescu ${ }^{1}\left(\mathbb{D}\right.$, Ana-Madalina Potcovaru ${ }^{2}{ }^{\mathbb{D}}$, \\ Constanta Alice Stefanescu ${ }^{1}$ and Irinel Marin ${ }^{1}$ \\ 1 Faculty of Management, The Bucharest University of Economic Studies, 010374 Bucharest, Romania; \\ mihai.bugheanu@man.ase.ro (A.-M.B.); ruxandra.dinulescu@man.ase.ro (R.D.); \\ alicestefanescu@yahoo.com (C.A.S.); irinel.marin@ase.ro (I.M.) \\ 2 Faculty of Administration and Public Management, The Bucharest University of Economic Studies, \\ 010374 Bucharest, Romania; ana.potcovaru@amp.ase.ro \\ * Correspondence: adriana.dima@man.ase.ro
}

check for updates

Citation: Dima, A.; Bugheanu, A.-M.; Dinulescu, R.; Potcovaru, A.-M.; Stefanescu, C.A.; Marin, I. Exploring the Research Regarding Frugal Innovation and Business Sustainability through Bibliometric Analysis. Sustainability 2022, 14, 1326. https://doi.org/10.3390/su14031326 Academic Editors: Eglantina Hysa, Félix Puime Guillén, Alba Kruja, Mirela Panait and Ahsan Akbar

Received: 31 December 2021

Accepted: 21 January 2022

Published: 25 January 2022

Publisher's Note: MDPI stays neutral with regard to jurisdictional claims in published maps and institutional affiliations.

Copyright: (C) 2022 by the authors. Licensee MDPI, Basel, Switzerland. This article is an open access article distributed under the terms and conditions of the Creative Commons Attribution (CC BY) license (https:// creativecommons.org/licenses/by/ $4.0 /)$.

\begin{abstract}
Nowadays, innovation is valued as being of utmost significance when evaluating measures of sustainable development and performance constructs. The current research develops investigations into the field of frugal innovation (FI) and how this process can contribute to business sustainability. This study performs a comprehensive evaluation of scientific production through the quantitative method of bibliometric analysis to facilitate our understanding of the current structure of studies and to highlight future research paths on FI and business sustainability. The paper maps the literature by narrowing its research topics and identifying certain patterns. Using the Web of Science database (WoS) on a sample of 2072 documents, descriptive and performance analyses were conducted. The VOSviewer software was used to perform the science mapping of the conceptual, intellectual, and social structure that provides scholars with a quantified and graphic representation of the FI and business sustainability field. The trend towards the analysis of business sustainability and consumer behaviour in the context of FI is highlighted. Annual scientific production and citation analysis reveal significant growth in international interest and scientific production, indicating an increasing line of inquiry for this topic at the start of the twenty-first century. The prominent scholars in the field are of European origin, while the highly active countries in the subject of FI and business sustainability are the USA, Germany, England, the Netherlands, and India, with major collaborations across the globe. This paper covers the limits identified by previous scholars by detailing the knowledge base and by using science mapping tools to document the structure of the literature; distinguish key journals, articles, and authors; and highlight new emerging topics of research.
\end{abstract}

Keywords: bibliometric analysis; business sustainability; frugal innovation; innovation; science mapping; sustainable development

\section{Introduction}

At this moment in time, the global economy is undergoing accelerated changes that seek to continuously satisfy societal requirements and to enhance public awareness towards the topic of sustainability. The concept of sustainability is becoming more and more popular since it covers three fundamental areas: environmental, social, and economic dimensions [1]. Consequently, the increasing interest in new alternatives to optimize the exploitation of various resources has heightened the need for researching new measures of sustainable behaviour and business models.

Of particular significance and complexity are the aspects concerning economic development and sustainable growth. In effect, the frugal concept is investigated and treated as a new technological paradigm that can represent a possible solution for how to improve the well-being of individuals. Under these circumstances, studies regarding sustainability 
issues, economic progress, and frugality have flourished, while the last concept is becoming treated as a disruptive innovation more and more. Considering this aspect, it is reasonable to conclude that the emerging phenomenon of frugality is especially derived from emerging markets. Accordingly, this new approach was initially adopted in emerging economies and then eventually in more developed markets.

As a result, frugality has received various definitions and is obviously dependent on specific contexts [2]. Generally, frugal innovation (FI) is a process that is characterized by efficiency, redesigning systems or products to develop a more affordable and accessible service.

Secondly, the main objective of the process is to solve a current challenge and to improve the overall standard of living. In other words, when discussing scarce resources, FI can provide a sustainable alternative to satisfy consumer needs in emerging economies or in low-income areas [3].

The theory of reverse innovation must be also remembered here because the two fields are related and often connected. Commonly, both theories are correlated, providing a strategical opportunity for companies attempting to implement sustainability in their organizational goal. From this perspective, the concepts are strongly questioned and explored by academicians and professionals together, thus evolving the phenomenon and enhancing the understanding around alternative methods of innovation.

What is more, the trend of FI is starting to develop its knowledge base and has become a favourite native topic of interest for researchers in recent years. For example, there are several names and titles linked to this phenomenon: "frugal innovation", "frugal engineering", "reverse innovation" [4], "constraint-based innovation" [5], "exnovation" [6], "blowback innovation" [7], "catalytic innovation" [8], "Gandhian innovation" [9], "grassroot innovation" [10], "no-frills innovation" [11], or "Jugaad innovation" [12]. Be that as it may, scholars differentiate between frugal and reverse innovation. The first concept is mostly specific to low-income countries and markets, while the second one is more specifically used for businesses or products that have been perfected in emerging sectors and then adapted for developed markets [13].

For this reason, it is becoming increasingly difficult to ignore the importance of new business models based on innovations in terms of frugality. The most compelling evidence, such modern business models, are becoming more and more used, not only in developing countries but also in matured and advanced regions [14,15].

Correspondingly, the theory of FI also has social influence, affecting aspects such as poverty, inclusive growth, and health concerns as well as environmentally sustainable development either directly or indirectly [16]. For example, modern frugal solutions help in the inclusion of marginalized lower-income individuals and benefit non-governmental organizations or entrepreneurship through less expensive services [17,18]. Henceforth, economic and social aspects should be analysed closely by considering the relationship between the two concepts.

On the positive side, the past decade has seen increasingly rapid advances in the field of limited resource solutions for low- and middle-income regions around the world $[19,20]$. To put it differently, due to its characteristics, frugality can be appreciated as a lifestyle [21] by considering the set of actions and norms that are involved in the new behaviour. After all, frugality involves austere behaviour both from consumers and companies who intend to decrease the impact of human actions towards essential resources [22].

However, understanding how various FI interact processes with business models and sustainable development remains a major challenge. A point that is often overlooked is that FI should be examined as an incentive for accomplishing sustainable development in advanced and matured countries [23]. Thus, the world is facing a new paradigm nowadays, in which production processes and the business models need to adapt to reduce resource consumption while increasing recycling procedures at the same time. 
Despite its acknowledged importance, the issue of FI remains insufficiently explored. In particular, frugality and financial performance can serve as a powerful driving factor for organizations [24] in addition to providing a sustainable business opportunity [6].

Although considerable research has been devoted to FI, less attention has been paid to how FI can promote social sustainability. In fact, the two concepts are inter-wined since FI advocates solving certain community issues. For example, energy, education, or health problems can all be addressed through FI, thus impacting society's environmental performance and significantly improving quality of life [25].

The novelty and the strengths of this paper are denoted by the fact that it reports and highlights the results collected by fundamental works on FI and business sustainability principles. The studies were extracted from the WoS database, from which 2072 publications were obtained. Specifically, the present work extends research on the FI field, using the bibliometric method to improve current knowledge on this topic.

Bibliometric analysis represents an important contribution to the field of FI and business sustainability research since it sets out a systematic method for selecting studies. Furthermore, the results of the available research can be utilized to emphasize the limits of knowledge in the selected study field and can thus identify existing research gaps more efficiently. In detail, the bibliometric review method is a statistical analysis of the scientific literature [22] that provides relevant statistics and a comprehensive picture for researchers who are working on evaluating the scientific activity in a particular field [26]. The method is also called science mapping and can be applied to a broad topic of interest or a more narrow domain $[27,28]$.

Additionally, bibliometric analysis serves as a helpful instrument that allows researchers to convert and reconstruct qualitative data into quantitative information. Secondly, the approach has implications in terms of identifying new trends in the field [29], documenting and integrating them into the knowledge base [30-32]. Thus, the findings and results from science mapping studies can provide new insights for scholars around the world.

Correspondingly, the present study proposes this approach because it provides a comprehensive view of the topic of FI. Secondly, the research can be used as a reference for academics who are interested in sustainable development and frugal behaviour later on.

Given these points, this study aims to evaluate the research that has been published on FI and business sustainability between the years 1976-2021 (one early access article in 2022) by addressing four research questions:

RQ1: What has been the distribution of scientific production on FI and business sustainability over the period under investigation?

RQ2: What are the main research methods that have been used by scholars to study FI and business sustainability in recent years?

RQ3: What are the main research clusters on FI and business sustainability?

RQ4: What are the significant research limitations and future research directions?

To find an answer to these research questions, the bibliometric review method was used to evaluate 2072 articles extracted from the WoS database. Therefore, the meta-data associated with these documents were analysed and tested. In particular, the research included various types of papers, such as citation analysis articles, descriptive statistics studies, as well as co-citation analysis articles. In the final analysis, the findings of the research allowed us to determine the essential driving agents and tendencies in FI processes as well as to investigate several gaps in the literature.

The study mentions the first use of the term "frugal" in academic research, which occurred in 1976. However, the concept from the 20th century is not similar to the concept from the 21st century, specifically "frugal innovation", which is studied in the current research.

In conclusion, this bibliometric analysis is significant for scholars as well as decisionmakers in both corporate and governmental organizations. For researchers, it includes important comments and proposals on theoretical research and also makes recommenda- 
tions on how research might be advanced using a holistic approach that supports conceptual and analytical grounds. The current research assists decision-makers in guiding their FI strategies and actions towards business sustainability.

With this in mind, the remainder of this article is structured as follows: The next section presents the theoretical background and an ample analysis of the related literature. Next, the methodology framework is presented followed by the results in conjunction with an explanation of the findings. In the final part of the paper, the Discussion and Conclusions chapters will clarify the outcomes of the study.

\section{Literature Review}

\subsection{Frugal Innovation}

Emerging markets have always been the origin of FI. The key goal was to provide goods and services that met the specific demands and requirements of these markets while still being affordable enough for consumers who were less well-off to take advantage of them. The Economist (2012) calls these frugal innovations (FIs) "reverse innovation," but they have also made their way into developed markets and are commonly referred to as such [4]. The distinction between frugal and other forms of innovation has been made through the use of several theories and frameworks. Most of them are based on reviews of previous research (for an overview, see Table 1). According to Cunha et al. [33], there are a lot of papers out there on scarcity and product innovation.

FIs are developing both in terms of quantity and quality [34,35]. Traditional innovations do not provide as much commercial and societal benefit as frugal ones. FI is defined by Angot and Ple [17] as having three key characteristics: affordability, high performance, and long-term viability. Hartley [36] provides proposals to encourage academics, managers, and policymakers to take a fresh look at innovative methods. According to van Beers et al. [37], enterprises should produce FI by beginning with the demands of impoverished clients and working their way backwards by only focusing on the most important components of their products. A key part of frugal thinking is the capacity to solve issues without being hampered by financial, resource, or institutional restrictions. It is suggested in the conceptual paper written by Soni and Krishnan [38] that FI should not be seen as an all-encompassing notion. Thus, it will be defined as a philosophy or way of life, as a process, and as output in the form of goods or services. Instead of creating differences between FI and other forms of innovation, the authors try to create a an FI typology.

FI differs from conventional innovation in four ways: the driver, the method, the fundamental capabilities, and the location of the invention. Therefore, it can be stated that FI is driven by what people really need as opposed to what they would want to have. Conventional innovation is all about what people want [18]. FI is discussed as both a product and a process in the academic literature. According to Soni and Krishnan [38], the method is known as frugal engineering, and the result is FI. Similarly, Brem and Wolfram [39] came to the same conclusion. The process is referred to as FI by Basu et al. [18] and George et al. [40], who see it as a multifaceted process rather than just a result.

Other resource-constrained innovation forms are examined by Zeschky et al. [19]. They conceptualize the differences between FI, good-enough innovation, and affordable innovation. Technical novelty and market novelty are used to classify FI. According to them, FI has a greater level of technical and commercial uniqueness than good-enough or cost-saving innovations. In addition, cost innovation implies the same thing for less: good enough innovation means adapted for less, and FI means new for less. 
Table 1. FI concepts.

\begin{tabular}{|c|c|c|c|}
\hline & Authors & Particularities & $\begin{array}{c}\text { Differences between FI and Various Types } \\
\text { of Innovation }\end{array}$ \\
\hline \multirow{4}{*}{$\begin{array}{l}\text { FI concepts and } \\
\text { frameworks }\end{array}$} & $\begin{array}{l}\text { Soni and } \\
\text { Krishnan [38] }\end{array}$ & Present three forms of FI & $\begin{array}{l}\text { When it comes to FI, it may refer to a philosophy } \\
\text { or a way of life as well as a process and a result } \\
\text { in the form of products and services. }\end{array}$ \\
\hline & Zeschky et al. [35] & $\begin{array}{l}\text { Technical and commercial uniqueness } \\
\text { Criteria: same for less, tailored for } \\
\text { less, and new for less. }\end{array}$ & $\begin{array}{l}\text { FI has greater technical and superior } \\
\text { market novelty than good-enough } \\
\text { innovation and cost innovation. } \\
\text { FI means new for less, budget } \\
\text { innovation = same for less, and good-enough } \\
\text { innovation = customized for less. }\end{array}$ \\
\hline & $\begin{array}{l}\text { Brem and } \\
\text { Wolfram [39] }\end{array}$ & $\begin{array}{l}\text { Sophistication, sustainability, and } \\
\text { evolving market orientation }\end{array}$ & $\begin{array}{l}\text { FI has low to moderate sophistication, moderate } \\
\text { sustainability, and medium developing } \\
\text { market focus. }\end{array}$ \\
\hline & Cunha et al. [33] & Field of scarcity & $\begin{array}{l}\text { - } \quad \text { FI: wealthy consumers are few. } \\
\text { - } \quad \text { Bricolage: material resources are limited. } \\
\text { - Improvisation: time is precious. }\end{array}$ \\
\hline \multirow{2}{*}{$\begin{array}{l}\text { Guidelines and } \\
\text { fundamentals } \\
\text { of FI }\end{array}$} & $\begin{array}{l}\text { Kumar and } \\
\text { Puranam [41] }\end{array}$ & Revealing six basic principles of FI & $\begin{array}{l}\text { Fundamentals: resilience, mobility, de-featuring, } \\
\text { leapfrog technology, mega-scale manufacturing, } \\
\text { and service ecosystems. }\end{array}$ \\
\hline & $\begin{array}{l}\text { Radjou and } \\
\text { Prabhu [42] }\end{array}$ & Revealing six basic principles of FI & $\begin{array}{l}\text { Principles: interact and iterate, expand your } \\
\text { assets, develop sustainable solutions, impact } \\
\text { consumer behaviour, co-create value with } \\
\text { prosumers, and build make unique friends. }\end{array}$ \\
\hline
\end{tabular}

Further articles help to provide our foundation for understanding FI and frugal engineering via the examination of underlying ideas. The paper by Kumar and Puranam [41] identifies six key concepts for service ecosystems and mega-scale production (see Table 1). In addition to the six principles outlined by Radjou and Prabhu [42], there are six more to consider: interact and iterate; flex your assets; build sustainable solutions; influence consumer behaviour; co-create value with prosumers; and make innovative acquaintances. The literature discusses additional ideas and requires competencies for developing frugal and associated innovations $[9,43]$.

Recent years have seen an increasing number of ideas from developing nations, many of which are labelled "frugal innovations" [44]. FI has a crucial role in inclusive innovation [45], and it has become more vital for social and political empowerment at the grassroots level [40]. FI attempts to decrease technical complexity to deliver value to clients in resource-scarce circumstances [46].

India is at the forefront of the FI phenomenon [46,47], which varies from traditional innovation in terms of novelty, target market [48], and business strategy. Prior research has offered some basic insights into how FIs serve disadvantaged clients in emerging countries [45].

FI is particularly promising in resource-scarce areas because of its focus on inexpensive, excellent-quality goods. A fundamental issue here is how to generate fresh services with minimal resources [49], and some enterprises compete without the advantages of resources, core technologies, or market dominance. This phenomenon is examined from a composition-based approach that highlights how ordinary enterprises with minimal resources can create great outcomes [50]. Hence, precisely understanding local events and producing theoretical knowledge beyond national borders is vital [51]. FIs employ context-sensitive techniques to serve low-income consumers, and innovations that originate at the grassroots level of developing nations typically satisfy these customers' needs [52]. Due to the absence of transferrable expertise in developing economies, Western corpora- 
tions occasionally see home-based product creation as a feasible strategy for satisfying the demands of low-income clients [53].

Along with established enterprises, many innovators at the grassroots level, sometimes with low education and technical skills, produce innovations using outside-the-box thinking [54], and information transmission may occur informally at this level (Figure 1). Therefore, these innovators provide sustainable solutions that incorporate local resources and reuse discarded components. The FIs that emerge at the grassroots level in emerging economies may have a big influence on society since they serve underserved clients and promote sustainability $[55,56]$. Similar any other sort of invention, however, a proper business strategy is essential for commercial success.

Proposal of value

- No electricity needed;

- Affordable product;

- Product aimed for a certain market;

- Women's independence;

- Convenient access to frugal products;

- Long-lasting product.

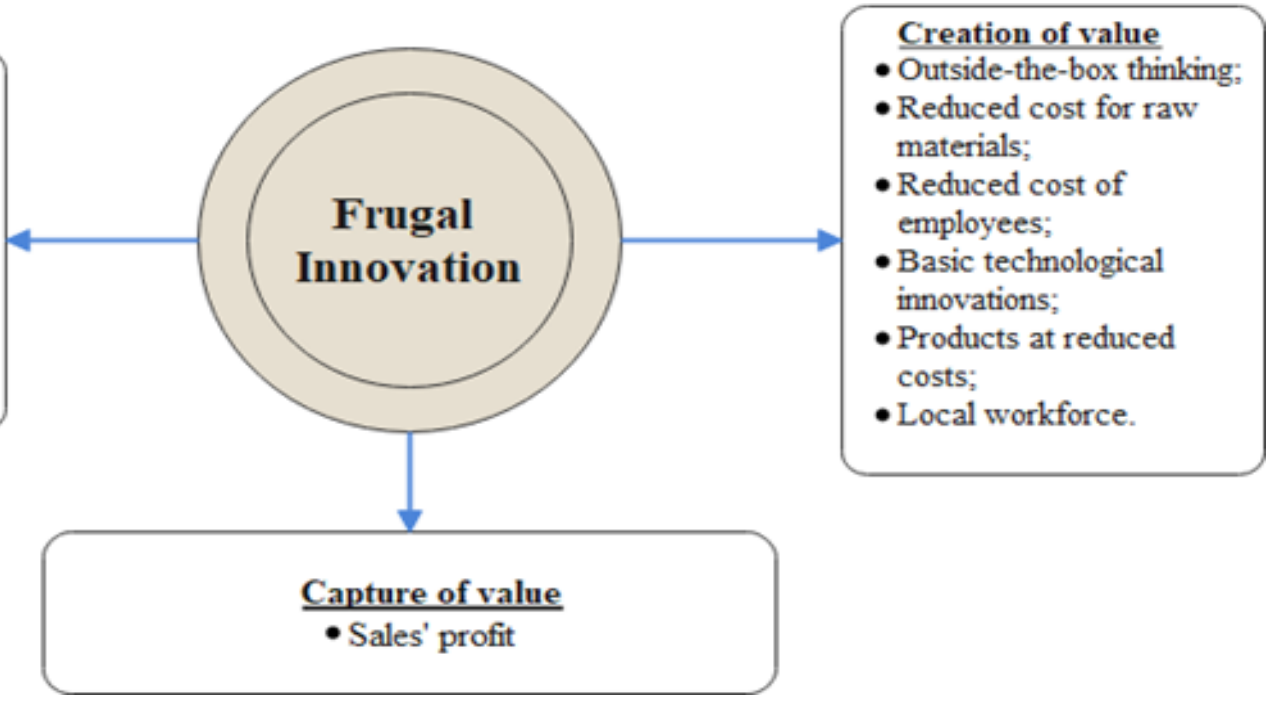

Figure 1. A concept for sustainable business initiatives for FI.

\subsection{Sustainable Business Development}

The literature on sustainable business development has grown quantitatively over time. Sustainability is a nebulous term $[45,56]$ that can be used in many ways and has different meanings. However, we take the opinions of the scholars who consider sustainability as a combination of the following dimensions into consideration: economic, social, and environmental $[45,57-60]$. An appropriate approach to sustainable development should balance and harmonize all of them [61]. Sustainable development refers to connecting different economic, social, and environmental concerns [62]. In their research, Wang et al. [63] argue that developing sustainability should be carried out by following three dimensions: economic (profit), social (people), and environmental (planet). Scholars have used the triple bottom line (TBL) concept for firms to achieve sustainability and long-term economic viability [64]. Triple bottom line and corporate sustainability were integrated and linked to responsible consumption and production (RCP) for the first time in the research by Wang et.al. [63]. The term TBL was adopted by Elkington in 1998 and comprised the same three dimensions: economic (profit), social (people), and environmental (planet) [65]. Other authors have attempted to integrate profit, people, and planet into corporate culture [66]. In sustainable business practices, the economic, social, and environmental factors are important [67], and its performance depends on the combination of these three elements.

Innovation is a key issue [68] and a crucial element [69] of sustainability and is considered a tool that can be used to support sustainable development [70]. However, sustainability is generating a variety of social innovations, such as innovative technologies [71] that aim is to improve the well-being of people in society [72]. These innovative technologies practice different types of sustainable development [71] and play an important role in sustainability [73].

Technological innovation and community action are important factors of sustainable development [71] that are rarely linked together. The current literature features limited re- 
search about the impact of technological innovation on achieving sustainable development; however, several scholars have highlighted the importance of technological innovation in obtaining sustainability [74]. Technological innovation is a critical instrument and can be used as a tool for achieving the economic, environmental, and social targets of sustainable development [74] and represents a significant channel for achieving sustainable services and products [74]. Technological innovation in high-income countries encourages investors to use innovative technologies [75].

In 2015, to increase quality of life, the United Nations proposed a series of goals called the sustainable development goals (SDGs) and formed of 17 goals and 169 related targets (sub-goals) [76]. The economic, environmental, and social cons of the sustainable development goals are also considered [77]. Researchers have highlighted that sustainable manufacturing is necessary to meet the objectives of 12 of the SDGs, as it connected to responsible consumption and production (RCP) $[76,78,79]$. The SDGs underline the need for sustainable consumption and production [61]. FIs provide the means to achieve the sustainable development goals by bringing different stakeholders closer to endeavours that achieve the SDGs. The aim is to increase the integration of local communities in the development planning process and to incorporate the three components of sustainable development in the triple line bottom approach. (U.N, 2015). Sustainable development is a process for growth and progression that aims to create sustainability by equilibrating the economic, social, and ecological dimensions [80]. FI can be considered as a method to obtain social sustainability and achieve the United Nations Sustainable Development Goals [25].

A sustainable, innovative, and productive economy offers the appropriate methods for all people to satisfy their basic needs without compromising the quality of life of future generations [71]. The notion of corporate sustainability for meeting the needs of the present without compromising the needs of future generations is a central theme in different studies [81]. Moreover, the investigation of the association between sustainability reporting and business financial success is a frequently discussed topic in the literature, which has resulted in confusing empirical results over time [82].

A higher level of sustainable development is based on a reconsideration of grassroots initiatives between community action and sustainable innovation. The grassroots approach is a form of innovation that can be used to achieve sustainable development that creates alternatives for sustainable development [71].

Previous researchers have highlighted the importance of business models to support sustainable development strategies [63] that can provide value for customers [83]. A sustainable business model (SBM) integrates a triple bottom line approach that takes the stakeholders, the environment, and society into consideration. SBMs provide a competitive advantage by capturing and creating new value. In some authors' opinions, sustainable performance refers to a source of competitive advantage [84]. A business model has three important components: value proposition, value capture, and value creation [85]. Scholars have demonstrated that sustainable business models have certain advantages for organizations [86]. Research on sustainable business model innovation (SBMI) began relatively recently and is a key element of sustainability [86].

One central theme of the FI is the market environment in emerging and developing countries $[87,88]$. Developing countries are increasingly seeking products that are both good enough as well as affordable because there are customers who cannot pay for standard services and products [89]. Many small firms from developing countries have identified new practices to gain a competitive advantage [45], and they are developing products and services to meet the needs underserved customers who are unable to afford existing services and products, thereby contributing to sustainability [90]. However, research in this domain remains limited.

Sustainable innovation is a specific notion for FI [91], but FI should be defined independently. FI has emerged as a novel method to help low-income customers in developing countries. Frugal products offer low-income individuals a way to accomplish their basic 
needs. FI can help underserved customers in developing countries and can play a crucial role in sustainable development [89].

Manufacturers have been forced to adapt to sustainable supply chain management. One practice is to obtain sustainability in supply chain management, and the practice is to close the loop of the supply chain by integrating reverse logistics in the supply chain. Sustainability can be described in terms of economic, environmental, and social factors [92]. Firms need to concentrate on delivering affordable solutions to customers while maintaining sustainability as a key element $[45,93,94]$, and they should open up new market segments [95]. To better describe the notion of "sustainability", Table 2 presents five well-defined concepts.

Table 2. Concepts of sustainability.

\begin{tabular}{ll}
\hline Inigo and Albareda [96] & $\begin{array}{l}\text { The five components of sustainable innovation are operational } \\
\text { components, collaborative components, holistic components, } \\
\text { instrumental, and organizational components }\end{array}$ \\
\hline Kim et al. [97] & $\begin{array}{l}\text { Along with economic aspects, technological and environmental } \\
\text { aspects trigger sustainability solutions }\end{array}$ \\
\hline Yong et al. 2020, p. 5 [98] & $\begin{array}{l}\text { Sustainability refers to business success not just in financial terms but } \\
\text { also in social and environmental terms }\end{array}$ \\
\hline Kuckertz and Wagner [99] & $\begin{array}{l}\text { Sustainability is a paradigm that can function as a reference point in } \\
\text { developing solutions to face environmental and societal challenges }\end{array}$ \\
\hline Dressler and Bucher [100] & Achieving sustainability means rethinking economic growth completely \\
\hline
\end{tabular}

\subsection{Sustainable Business Development and FI}

A large part of the literature on the connection between FI and sustainable business development explores the theoretical relationship between the two concepts. From this perspective, the first point to mention is that FI is not inherently conducive to sustainable development. FI is mainly targeted to low-cost products for less rich consumers and should be distinguished against sustainable innovation, which directly aims to improve social and environmental performance. However, most authors find a positive link between FI and sustainable development. Among the three pillars of sustainability-economic, social, and environmental - the last one is especially considered. Since FI is characterized by the minimization of the use of material and financial resources when preserving or even exceeding quality standards, sustainable development can be defined as "development that meets the needs of the present without compromising the ability of future generations to meet their own needs". FI contributes to sustainable development through saving resources and decreasing waste. In more detail, the positive relationship between FI and sustainable development is obtained through specific channels. First, since frugal products contain less functionality, FI reduces the amount of resources and materials used [6]. Secondly, frugal products are technologically simpler, making them easier to repair [101,102]. Thirdly, frugal products are usually obtained by a frugal manufacturing process that has been designed to save natural resources [102]. Fourthly, frugal products are built to last for a long time and to avoid waste, something that is in direct opposition to the practices of planned obsolescence. These arguments usually ensure a positive link between FI and sustainable development.

Despite this, frugal products are not inherently "greener". FI's focus on affordability can impede sustainability effects [103]. Environmentally friendly solutions are often expensive. Particularly, the extraction of raw materials for frugal products creates many environmental problems [104]. At the same time, businesses that use FI fail to take into consideration the recycling, reuse, and disposal of products [23]. Consequently, to be sustainable, FIs should consider the whole value chain. Another problem could be that the affordability of frugal products can encourage increased consumption [23,61].

Another part of the literature deals with empirical studies concerning the relationship between FI and sustainability. Wohlfart et al. [105] explore the distinction between corpo- 
rate and grassroots FI through case studies as well as from a sustainability perspective. Corporate FI regards the solutions implemented by large companies, while grassroots FI starts from solutions designed by common people and small entrepreneurs. The article examines all three pillars of sustainability, and it concludes that grassroots FI is focused on social sustainability, while corporate FI emphasizes economic sustainability. For both categories, environmental sustainability is a secondary motivation [105]. Hossain et al. [89] also examine the empirical relationship between grassroots FI and the three pillars of sustainability through case studies. The main conclusion that can be drawn from the three case studies is that FI plays a greater role in the social and economic aspects but that the environmental aspect is also present. FI can be profitable without sacrificing environmental sustainability.

Knorriga et al. [106] also stress that the environmental sustainability of FIs is a matter of empirical research but not an obvious result. Many solutions that can be considered FIs are not, such as the "cheap batteries or solar cells produced in Asia and sold in rural Africa", and do not really satisfy the conditions of sustainability. Hyvärinen et al. [104] examine the pitfalls of FI through a case study on the water treatment solution in Tanzania. The authors stress that the purpose of providing cheap production is not always compatible with sustainable development. They also show that the whole value chain should be examined to assess the sustainability level of an FI. Focused on the social pillar of sustainability, a framework was built to assess the social sustainability performance of a product or service. This framework contains four factors: (1) the frugal characteristics; (2) social value and social impact; (3) the most significant stakeholders; and (4) the most significant social assessment areas. Levänen et al. [107] examines four cases of FI from a sustainability perspective by considering the social, economic, and environmental perspectives. The main result was that the analysed FIs were more sustainable than previous solutions but that there are also some important challenges that need to be addressed [107].

The relationship between sustainable development and FI is an emerging field of research development, and some authors have linked the two concepts to responsible consumption and production [81]. However, FI contributes to sustainable development in both emerging and advanced economies [91].

According to some authors, FI can be a tool [61] and may have significant potential for sustainable development because they elements of sustainability out of necessity [45]. FI is also a catalyst for sustainable development [23]. FI contributes to sustainable development by serving underserved customers with affordable products [45]. FI represents the interaction between constraints, performance, and innovation [108]. According to other researchers, FI is a special kind of environmental innovation [102]. Resource-constrained innovations create new low-cost segments of existing markets [109], and FIs create new markets and contribute to sustainability [45].

FI increases the sustainability of the economy because it saves raw materials, some physical resources, and inputs. A frugal product is more reliable and has fewer components and a minimalistic design [110]. The sustainable character of frugal products is also enhanced by the fact that local products are used [111]. At the same time, some products that are the result of frugal innovation are environmentally friendly [111]. Organizations use bricolage in order to recombine available resources to deliver greater value [112].

On the other hand, some authors consider that being sustainable is not the main priority of FI [102]. Other findings show that frugality may not involve sustainability [109].

Some studies, however, do indicate that cost and sustainability should be considered together when creating frugal products. Frugality is a formative conception that incorporates the following dimensions: simplicity, sustainability, basic quality, and cost of consumption [111]. Other authors consider that a frugal product embraces four characteristics: local, proximity, global diffusion, and distance. Physical proximity to the target market is important for FI [113-115].

Because of its emphasis on the frugal utilization of resources, the inclusion of lowincome actors, and its nature of gathering participants, FI may be promising for sustainable 
development approaches. Baud [116] expands on the work of Knorringa et al. [106] and argues that for FI to support more inclusive development processes, three conditions need to be achieved: First, enterprises should market inexpensive frugal goods and services.

Second, low-income entities should be involved in value chain activities. Third, natural resources should be utilized in a thrifty way. Cunha et al. [33] suggest that FI presents an essential significance when it comes to establishing a future in which enterprises confront greater societal demands to incorporate sustainability in their operations and to learn how to accomplish more with less.

Despite the theoretical similarities between sustainable development and FI offered by experts, this area has not been investigated in depth. Although various scholars do stress the possible ties between the two concepts, the arguments revolve around the same themes, notably the decreased utilization of resources over the full product life cycle, inexpensive basic products/services, and the involvement of low-income actors. However, sustainable development is a comprehensive notion with various aspects and interrelationships. Thus, a holistic approach is essential.

Several academics have previously pointed out the possible contributions of FI to different elements of sustainability. FIs may contribute to sustainable development by supplying developing communities with the increased decision to acquire products that fit their demands, limiting the usage of natural resources and generating inclusive economic growth through the participation of the community in the value chain $[106,113]$. Simultaneously, FIs provide profit potential to enterprises-satisfying the profit motive, which — while not the only motivator for a corporation to participate in sustainable activities-is nevertheless a significant one [117-119]. However, recent empirical evidence has revealed that FIs are not intrinsically sustainable [61]. The supply of affordable goods and services does not address the structural foundations of poverty [120]. Similarly, decreasing resource utilization may not immediately result in environmental preservation. Sustainable development is seen as socially inclusive, and environmentally friendly economic growth is an elaborate, multidimensional task that requires interventions at many levels and from diverse stakeholders [121].

Because FI and business sustainability are two major concepts in academic research, Table 3 presents 20 previous articles that have been analysed in a specific manner. Furthermore, the table presents 20 of the most cited articles on FI and business sustainability published between 2020 and 2021.

Analysing Table 3, numerous and diverse research methods that have been used by scholars can be observed in the research published during the years 2020 and 2021. Because the notion of "frugal innovation" is a vast concept and how it is applied is different in different industries, there are several research methods that have been used by authors to better demonstrate the advantages of this method. One strength of this analysis is that the authors show that frugal innovation is emerging from numerous sources, and it is analyzed from different levels, perspectives, and units. On the other hand, the weakness of this analysis is that no unitary approach emerges from the above research on the articles. This shows how complex the approach to frugal innovation is.

The following are the most commonly used research methods: analysing the strategic knowledge transfer strategies, interviews conducted with the university employees, developing frameworks for the dimensions of cost-effective innovation enablers in SMEs, investigating the impact of the entrepreneurial ecosystem, building a criteria-based evaluation approach, etc. 
Table 3. Previous literature analysis.

\begin{tabular}{|c|c|c|c|c|c|}
\hline Year & Subject Area & Author & Purpose & Methodology/Sample & Findings \\
\hline 2020 & Business & $\begin{array}{l}\text { Kristoffersen, E; Blomsma, F; } \\
\text { Mikalef, P; Li, JY [122] }\end{array}$ & $\begin{array}{l}\text { Putting circular strategies at the heart of } \\
\text { manufacturing companies' ambitions to } \\
\text { contribute to the UN's 12th Sustainable } \\
\text { Development Goal. }\end{array}$ & Based on three iterative phases & $\begin{array}{l}\text { Present techniques for providing extra value } \\
\text { propositions to customers while eliminating or } \\
\text { lowering structural waste. }\end{array}$ \\
\hline 2020 & $\begin{array}{l}\text { Business; } \\
\text { environmental studies; } \\
\text { management }\end{array}$ & $\begin{array}{l}\text { Dey, PK; Malesios, C; De, D; } \\
\text { Budhwar, P; Chowdhury, S; } \\
\text { Cheffi, W. [123] }\end{array}$ & $\begin{array}{l}\text { Techniques, resources, and competencies for } \\
\text { attaining sustainability in all CE fields of action }\end{array}$ & $\begin{array}{l}130 \text { randomly selected SMEs within } \\
\text { the Midlands of the United Kingdom }\end{array}$ & $\begin{array}{l}\text { The CE sectors of SME activity (take, make, distribute, } \\
\text { use, and recover) are related to economic performance, } \\
\text { but only take and use are relevant to environmental } \\
\text { and social performance. }\end{array}$ \\
\hline 2020 & $\begin{array}{l}\text { Business; development } \\
\text { studies; management }\end{array}$ & $\begin{array}{l}\text { Ritter-Hayashi, D; Knoben, J; } \\
\text { Vermeulen, PAM [124] }\end{array}$ & $\begin{array}{l}\text { Downsizing has been shown to have a } \\
\text { detrimental effect on innovation in industrialized } \\
\text { countries. However, the influence of downsizing } \\
\text { on innovation remains unknown in emerging } \\
\text { countries. }\end{array}$ & $\begin{array}{l}\text { A study across nine developing } \\
\text { countries in Africa and South Asia; } \\
\text { follow-up survey for } 2912 \text { firms. }\end{array}$ & $\begin{array}{l}\text { Downsizing has a damaging effect on process } \\
\text { innovation. However, labour flexibility enables } \\
\text { businesses to remain inventive despite downsizing. }\end{array}$ \\
\hline 2021 & $\begin{array}{l}\text { Information science } \\
\text { and library science; } \\
\text { management }\end{array}$ & $\begin{array}{l}\text { Fischer, B; Guerrero, M; } \\
\text { Guimon, J; } \\
\text { Schaeffer, PR [125] }\end{array}$ & $\begin{array}{l}\text { Analyses the strategic knowledge transfer } \\
\text { strategies used by an entrepreneurial institution } \\
\text { to generate FIs in a developing country. }\end{array}$ & $\begin{array}{l}14 \text { interviews conducted at the } \\
\text { University of Campinas (Unicamp) }\end{array}$ & $\begin{array}{l}\text { The complex dynamics of frugal discoveries spawned } \\
\text { by university-industry collaboration. }\end{array}$ \\
\hline 2020 & Business & $\begin{array}{l}\text { Niroumand, M; Shahin, A; } \\
\text { Naghsh, A; Peikari, HR [126] }\end{array}$ & $\begin{array}{l}\text { Present a framework for the dimensions of } \\
\text { cost-effective innovation enablers in small and } \\
\text { medium-sized businesses (SMEs). }\end{array}$ & $\begin{array}{l}200 \text { employees and managers of } \\
\text { SMEs in the home appliance } \\
\text { manufacturing industry of Isfahan } \\
\text { province }\end{array}$ & $\begin{array}{l}\text { The most important FI enablers are world-class } \\
\text { design, human aspect, marketing, support, } \\
\text { knowledge, social aspect, prototyping, cultural aspect, } \\
\text { environmental aspect, distinct brand creation, core } \\
\text { functions focus, local R\&D, cost-cutting business } \\
\text { model, and low-cost production. }\end{array}$ \\
\hline 2020 & Business & $\begin{array}{l}\text { Igwe, PA; Odunukan, K; } \\
\text { Rahman, M; Rugara, DG; } \\
\text { Ochinanwata, C [127] }\end{array}$ & $\begin{array}{l}\text { Investigate the impact of the entrepreneurial } \\
\text { ecosystem and institutional context on the } \\
\text { development of FI and informal entrepreneurship }\end{array}$ & $\begin{array}{l}20 \text { business owners in Nigeria and } \\
\text { two focus groups meeting with } 5 \text { and } \\
7 \text { business associations leaders. }\end{array}$ & $\begin{array}{l}\text { A model of the factors of FI and informal } \\
\text { entrepreneurial ecosystem, which includes } \\
\text { formal/informal norms, market access, and family as } \\
\text { crucial elements that serve as a method of successful } \\
\text { information flows, networking, money, and } \\
\text { resource sharing. }\end{array}$ \\
\hline 2020 & Management & $\begin{array}{l}\text { Agarwal, N; Brem, A; } \\
\text { Dwivedi, S [128] }\end{array}$ & $\begin{array}{l}\text { A case study analysis approach was used to } \\
\text { evaluate this shift and the process of creation of } \\
\text { these innovations. }\end{array}$ & $\begin{array}{l}9 \text { interviews with leading } \\
\text { R\&D experts }\end{array}$ & $\begin{array}{l}\text { In local R\&D projects, continuing innovation develops } \\
\text { and provides insights into the production of } \\
\text { cost-effective products. }\end{array}$ \\
\hline 2020 & Business & $\begin{array}{l}\text { Borchardt, M; Pereira, G; } \\
\text { Ferreira, AR; Soares, M; } \\
\text { Sousa, J; Battaglia, D [129] }\end{array}$ & $\begin{array}{l}\text { Through the theoretical lens of dynamic } \\
\text { capacities, this article examines the elements that } \\
\text { drive FI in micro- and SMEs at the base of the } \\
\text { pyramid (BOP). }\end{array}$ & $\begin{array}{l}25 \text { MSEs at the BOP in Brazil, all of } \\
\text { which were in the food industry. }\end{array}$ & $\begin{array}{l}\text { This study shows that firms migrating to low-and } \\
\text { middle-income consumers possess dynamic skills, } \\
\text { which influence their financial management methods. }\end{array}$ \\
\hline 2020 & Business; management & $\begin{array}{l}\text { Winkler, T; Ulz, A; Knobl, W; } \\
\text { Lercher, H [130] }\end{array}$ & $\begin{array}{l}\text { Build a criteria-based evaluation approach to } \\
\text { better understand FIs and the reasons for their } \\
\text { success or failure in developed markets }\end{array}$ & $\begin{array}{l}\text { Three case studies are analysed with } \\
\text { the adapted evaluation model }\end{array}$ & $\begin{array}{l}\text { The success and/or failure of FIs as well as the } \\
\text { concept of FI itself are heavily influenced by the } \\
\text { market in which they are launched. }\end{array}$ \\
\hline
\end{tabular}


Table 3. Cont.

\begin{tabular}{|c|c|c|c|c|c|}
\hline Year & Subject Area & Author & Purpose & Methodology/Sample & Findings \\
\hline 2020 & $\begin{array}{l}\text { Engineering, } \\
\text { multidisciplinary; } \\
\text { management; } \\
\text { operations research; } \\
\text { management science }\end{array}$ & $\begin{array}{l}\text { Wimschneider, C; Agarwal, } \\
\text { N; Brem, A [131] }\end{array}$ & $\begin{array}{l}\text { The study examines FI and its acceptance } \\
\text { in Brazil. }\end{array}$ & Research on six Brazilian companies. & $\begin{array}{l}\text { Cost-effectiveness and ease of use are the two primary } \\
\text { elements of FI. }\end{array}$ \\
\hline 2020 & $\begin{array}{l}\text { Sustainability; } \\
\text { RFID;CLSC } \\
\text { (closed-loop supply } \\
\text { chains); } \\
\text { RL (reverse logistics); } \\
\text { CLSCs/RL (loop } \\
\text { supply chains or } \\
\text { reverse logistics) }\end{array}$ & $\begin{array}{l}\text { Usama, M; Ramish, A } \\
\text { [92] }\end{array}$ & $\begin{array}{l}\text { Develop a typology and to propose the } \\
\text { framework to define RFID in the CLSC/RL by } \\
\text { categorizing the products based on RFID }\end{array}$ & $\begin{array}{l}\text { A literature review is based on three } \\
\text { theories related to the configuration } \\
\text { of RFID in the CLSC/reverse } \\
\text { innovation and observations }\end{array}$ & $\begin{array}{l}\text { Two typologies were developed: pre-tagging and } \\
\text { post-tagging regarding the deployment of RFID in } \\
\text { CLSC/RL along with the categorization of products as } \\
\text { single-piece and multi-piece products. } \\
\text { The fourth typology proposed was "End-to-end } \\
\text { supply chain tracking" } \\
\text { Additionally, a framework for configuring RFID in } \\
\text { reverse logistics was also proposed. }\end{array}$ \\
\hline 2020 & $\begin{array}{l}\text { FI; frugal patent; } \\
\text { patent search; } \\
\text { text-mining; semantic } \\
\text { patent analysis }\end{array}$ & $\begin{array}{l}\text { Altgilbers, N; Walter, L; } \\
\text { Moehrle, MG [95] }\end{array}$ & $\begin{array}{l}\text { Help researchers to better understand frugal } \\
\text { inventions and innovation } \\
\text { and to understand that frugal inventions can be } \\
\text { patented (based on extensive engineering work } \\
\text { with novel technical solutions). } \\
\text { The third goal was to deliver a multitude of } \\
\text { frugal patents. }\end{array}$ & $\begin{array}{l}\text { Literature review (based on a large } \\
\text { spectrum of literature). Semantic } \\
\text { analysis on the role of frugal } \\
\text { attributes to qualify a frugal } \\
\text { invention candidate as a frugal } \\
\text { patent. }\end{array}$ & $\begin{array}{l}\text { A frugal thesaurus was developed by combining pairs } \\
\text { of categories, and managers may use this method to } \\
\text { search for frugal patents developed by their } \\
\text { competitors (they developed a four-step process and } \\
\text { used medical engineering technology as a promising } \\
\text { text-bed). Theoretical implications and the } \\
\text { transferability of the process model to other } \\
\text { technological fields as a managerial implication. They } \\
\text { proposed a four-step process model based on frugal } \\
\text { attributes: operationalisation, patent search, patent } \\
\text { processing, assessment }\end{array}$ \\
\hline 2020 & $\begin{array}{l}\text { Inclusive growth; } \\
\text { cost FI; }\end{array}$ & Kroll, H; Gabriel, M [91] & $\begin{array}{l}\text { Demonstrate how FIs may be applicable in } \\
\text { European economies }\end{array}$ & $\begin{array}{l}\text { Qualitative research based on } \\
40 \text { phone interviews } \\
\text { with stakeholders }\end{array}$ & $\begin{array}{l}\text { FI should maintain a priority on balancing economic, } \\
\text { social, and environmental sustainability. } \\
\text { FI should be explored by European countries that are } \\
\text { facing issues with market responsiveness. }\end{array}$ \\
\hline 2020 & $\begin{array}{l}\text { FI; bricolage capability; } \\
\text { resource-constrained } \\
\text { environments; context } \\
\text { of crisis; innovation } \\
\text { strategy; } \\
\text { emerging markets }\end{array}$ & $\begin{array}{l}\text { Santos, LL; Borini, FM; } \\
\text { Oliveira, MD; Rossetto, DE; } \\
\text { Bernardes, RC [132] }\end{array}$ & $\begin{array}{l}\text { Identify if companies from emerging markets } \\
\text { could develop FIs that depend on } \\
\text { bricolage capability. }\end{array}$ & $\begin{array}{l}\text { Data were collected from a survey } \\
\text { applied to } 215 \text { companies in Brazil. } \\
\text { The method used was the structural } \\
\text { equation modelling technique, and } \\
\text { the hypotheses were tested } \\
\text { statistically. }\end{array}$ & $\begin{array}{l}\text { Bricolage capability has a positive impact on the } \\
\text { development of FI. In an emerging market affected by } \\
\text { resource scarcity, bricolage could be seen as a key } \\
\text { managerial capability for the development of FI. }\end{array}$ \\
\hline
\end{tabular}


Table 3. Cont.

Year Subject Area

\section{Subject Area}

Author

Purpose

Methodology/Sample

Findings

Corona crisis, frugality

2020 4.0, circular economy;

$\mathrm{FI}$; affordable green

excellence
Herstatt, C; Tiwari, R [133]

Investigate how FIs can contribute to better manage the after-effects of the COVID-19 pandemic

Case studies: Germany from an

economic and social point of view; the difficulties faced by people during the

COVID-19 pandemic, which acts as a COVID-19 pandemic, which acts as a
driver for frugality and describes the driver for frugality and describes the acceptance for voluntary simplicity conduct frugality by choice. It is analysed the blue movement fromds and the transition to "Frugality 4.0".

2020 technological

Eco-innovation FI; environment paradigm; sustainability

Contribute to the literature on FI by conceptualizing FI as a new technological paradigm and considering FI as an environmental innovation

This study is the first large-scale empirical investigation of FI aiming to find that firms that experience a high level of resource constraints are more probable to produce FI. Another purpose was to demonstrate that firms from a highly resource-constrained external environment produce FI.

Vermeulen, P; van Beers, [134] efficiency

Responsible research

frugal; grassroots; innovations;

Bhaduri, S; Talat, N [135]

vulnerable; susta

resource-constrained innovation; emerging markets; developing markets

Neumann, L; Winterhalter, S; The study aims to analyse the consequences and Gassmann, O [88] implications of the market choice of the FI.

Find common aspects between responsible research and innovation (RRI) and the pro-social motivations that promote inclusive development.

An anglyic

An analytical study of frugality as a
new technological paradigm and the

environmental implications of FI: FI

and sustainability, FI and

circular economy.

A quantitative method was used that was based on surveys and data samples from 32,897 firms from 36 countries across Africa, Latin America, and Asia.

\section{Based on a qualitative method that} analyses how some of the elements of RRI are inherent in the FIs by the vulnerable.

This study is based on a multi-case study approach (cross-industry and cross-national), analysing 237 FIs cases evaluated using Atlas TI software. Data were collected from 57 semi-structured interviews.

\section{The study conducts a review based}

The paper (one of the first that links FI and leapfrogging innovation) and focuses on problem and investment dilemmas caused by the low affordability market, the stakeholder's problem, and the low capability of firms in responding to the industry 4.0 challenge. on the FI and leapfrogging

innovation literature and develops framework for solving the problem in responding to the Industry 4.0 challenge in Thailand
They contextualized the impact of the corona crisis on the economic and societal choices of people and in the field of innovation management. They propose a model that can be characterized as "affordable green excellence".

They define FI rigorously as a technological paradigm, and they show how FI can contribute to sustainable performance

The firm-level resource constraints have a strong effect on the firms. FI is used by firms as a useful strategy to deal with resource constraints.

Another finding was that the interaction between firm-level and firm-environment performance is a critical driver.

One important finding was that FIs tend to $b$ problem-solving, practical, and user-driven

The findings show that FI is a disruptive innovation to its respective target market, and they significantly influenced or changed the market.

Another finding shows that FI is placed on activities from the value chain and the main objective is cost savings and the affordability of the product or the service.

Firms and developing countries should take into account alternative innovation approaches, but this requires serious experimentation. 


\section{Materials and Methods}

The relevance of scientific publications has dramatically shifted in recent decades. Some of the key decisions in economic and political growth priorities, policy initiatives, funding allocation, partnership prospects, university staff hiring, etc., are presently supported by scientific production assessment. Research quality measured as the impact of a publication became an essential factor. The significance of a publication as a metric for research quality has become an important prerequisite [33].

Bibliometrics constitutes the branch of scientometrics that uses mathematical and statistical methods in order to assess the production of scientific publications. Bibliometric indicators are metrics that provide information on the performance of scientific activity in many of its expressions. The development of bibliometric analysis as a key scientific endeavour has increased rapidly in recent years, and bibliometrics has been widely used in a variety of study areas: agriculture [137-139], business [140,141], computer science [142], economics [143,144], geography [145], mathematics [146], tourism [147], and many others.

Bibliometric analysis is a critical component of moving a study area forward since it provides a comprehensive audit trail for sharing and legitimizing current research as well as laying the path for new studies to arise [148]. Bibliometric analysis investigates the formal attributes of fields of knowledge by using mathematical and statistical techniques by examining the networks established around the most representative keywords as well as the manner in which citations, scholars, affiliations, counties, and publications indicate the importance of specific topics in the field of research [79,149].

The objective of the present research is to evaluate how FI relates to business sustainability through the means of bibliometric analysis. Accordingly, this article aims to provide a critical overview of previous studies and to identify the trends and patterns in FI research, highlighting the most relevant related concepts and study gaps.

Thus, a bibliometric analysis is employed to address the aforementioned objective. The results reveal the structure, development, and main trends and implications of the FI and business sustainability research field by methodically identifying and assessing the scientific production, main contributions to the field, and major future research directions.

A protocol is essential for bibliometric analysis because it promotes meticulous planning, consistency in execution, and transparency that allows for study replication. In other words, a protocol allows researchers to foresee issues, eliminate arbitrary decisions, increase responsibility, and maintain study integrity [150]. The literature presents a series of protocols and research frameworks that can be applied in bibliometric analysis: PRISMAP [151], bibliometric protocol [152], bibliometric analysis toolbox [153], and research design of bibliometric analysis [154-157]. This research is based on the bibliometric protocol in Figure 2, which was developed after synthesizing the information from the mentioned sources and adapting the identified frames to the objectives of the study.

The planning of the review process, which begins with the formulation of research questions and the collection of data for analysis, represents the first phase in the bibliometric procedure. Clarivate's Web of Science (WoS) database was selected to retrieve the documents for the bibliometric analysis due to the fact that it is considered the oldest [33], most frequently used, and most reliable database of academic papers and citations in the world [158]. In addition, WoS is the first bibliographic database, founded in the 1960s, and is considered the "gold standard" for bibliometric analysis [137] compared to other more recent databases such as Scopus or Google Scholar, both of which were launched in 2004.

Several keyword combinations related to FI and business sustainability were applied in the WoS database (Table 4) depending on major possible variants of the term frugal related to innovation as identified in the literature and as presented in the previous section of the article. The search was performed on 6 December 2021, and, after removing duplicates, 2072 documents were selected on which to perform the analysis. No restrictions on the year of publication or language were applied because this research seeks to investigate the evolution of the concept of FI concerning business sustainability over time, and the 
imposition of such restrictions would affect the final results. Therefore, all 2072 publications identified in WoS between 1976 and 2021 were selected.

\section{Phase 1. Planning the Review Process}

Formulating the Research Questions
Developing the Research Protocol
Data Collection
- Database: WoS
- Timeline: 1976 - 2021
- Extraction date: 06 December 2021
- Publication dataset: $\mathrm{n}=2072$

\section{Phase 2. Conducting the Review} Process

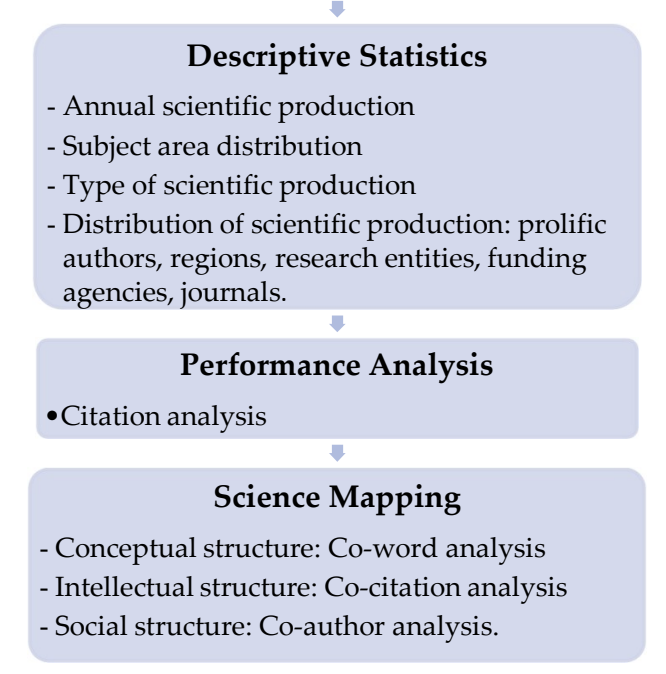

\section{Phase 3. Presenting the} Research Results

Analysing the Final Results

Stating the Final Insights of the Research

Figure 2. Research protocol.

Table 4. Keywords search results (6 December 2021).

\begin{tabular}{cc}
\hline Combination of Words & Research Results \\
\hline Frugal OR frugal innovation AND business sustainability & 1927 \\
Reverse innovation AND business sustainability & 147 \\
Frugal engineering AND business sustainability & 14 \\
Jugaad AND business sustainability & 4 \\
Exnovation AND business sustainability & 2 \\
Constraint-based innovation AND business sustainability & 2 \\
Blowback innovation AND business sustainability & 0 \\
\hline Total (after removing duplicates) & 2072 \\
\hline
\end{tabular}

The second phase in the bibliometric procedure represents the actual conducting of the review process, which includes the following techniques:

1. Descriptive Statistics-This trend analysis of scientific knowledge dissemination is performed to examine the evolution of annual scientific production, the distribution of documents based on document type, subject areas, prominent authors, countries of publication, research entities, and funding agencies.

2. Performance analysis-Used to investigate the evolution of the scientific production of the citations recorded for these documents in the period analysed.

3. Science mapping:

- Conceptual structure: Co-word analysis-Performed in order to identify often cooccurring authors and index terms related to the study issue under consideration. Examining the theme evolution over time to detect developing and saturated issues is required [152].

- Intellectual structure: Co-citation analysis-Performed to determine common themes in publications and to group documents into specific topics based on their conceptual structure. It serves as the foundation for the semantic clustering of documents in the same domain that are comparable [152,159].

- Social structure: Co-author analysis-Depicts the number of publications for certain variables and how they are related to one another, and bibliographic 
coupling exists when papers cite the same document. Such a method is applicable to institutions and also countries.

Science mapping was conducted using VOSviewer (version 1.6.17, Leiden University, Leiden, The Netherlands). VOSviewer is a software program that can be used to generate and display bibliometric networks based on co-citation, bibliographic coupling, or coauthorship links [160]. It also includes text mining functionality for creating co-occurrence networks of relevant terms collected from a collection of scientific literature [161]. The total link strength indicates the number of publications where two indicators (keywords, authors, citations, etc.) appear together.

The third phase in the bibliometric protocol is performed during phase two and refers to the presentation of the results obtained following the use of the techniques presented above. This is complemented by an in-depth content analysis and synthesis of the most prolific research papers in terms of citations. Finally, thematic areas and future research directions are identified and presented.

\section{Results}

\subsection{Descriptive Statistics and Trend Analysis of Scientific Knowledge Dissemination}

The following section of the paper presents the major characteristics of scientific production and an evaluation of the number of publications and citations, percentages of variance throughout intervals, the most published WoS categories, the main research domains, regional distribution of scientific production, the most prolific research agencies and funding institutes, and, finally, the total number of journals in which articles on the research topic under consideration are published.

\subsubsection{Annual Scientific Production}

Research intensified in the analysed field starting in 1996, which represents the period in which the number of citations for the published works also started to increase (Table 5). It is observed that in the last six years analysed, 2016-2022, the researchers' concerns regarding the relationship between FI and business sustainability were very high, and the number of citations tripled compared to the previous period, 2011-2015. For 2022, an early access publication that had already been indexed in WoS was identified, and this was included in the calculations and analyses performed, but to facilitate the information flow, the period 1976-2021 will be taken as a reference for the following analysis.

Table 5. WOS publication years.

\begin{tabular}{cccc}
\hline Years & Articles & Citations & $\begin{array}{c}\text { Average } \\
\text { Citations/Article }\end{array}$ \\
\hline $2016-2022^{*}$ & 1143 & 15,359 & 13.44 \\
$2011-2015$ & 457 & 5070 & 11.09 \\
$2006-2010$ & 254 & 2355 & 9.27 \\
$2001-2005$ & 102 & 682 & 6.69 \\
$1996-2000$ & 69 & 260 & 3.77 \\
$1991-1995$ & 29 & 48 & 1.66 \\
$1983-1990$ & 8 & 16 & 2.00 \\
$1976-1980$ & 10 & 0 & 0.00 \\
\hline
\end{tabular}

Source: own elaboration * An article has already been published through the early access system in 2022, and in 1981 and 1982, no publications on the analysed topic were registered.

According to the data, research on FI linked to business sustainability showed a positive trend throughout the entire analysed period (1976-2021, with one article already published for 2022), with a considerable increase starting in the year 2000 and then another important leap in 2015. From this date, the number of publications has experienced slight fluctuations, as seen in Figure 3. However, there has been a substantial increase in the publication number in the last five years compared to at the beginning of the analysed timeframe or even in the period of 2000-2010. This is also justified by the growing number 
of products included in the FI category that have been launched on the market in the last decade, which are based on previous research and studies. A total of 4841 authors contributed to this research theme with at least one document.

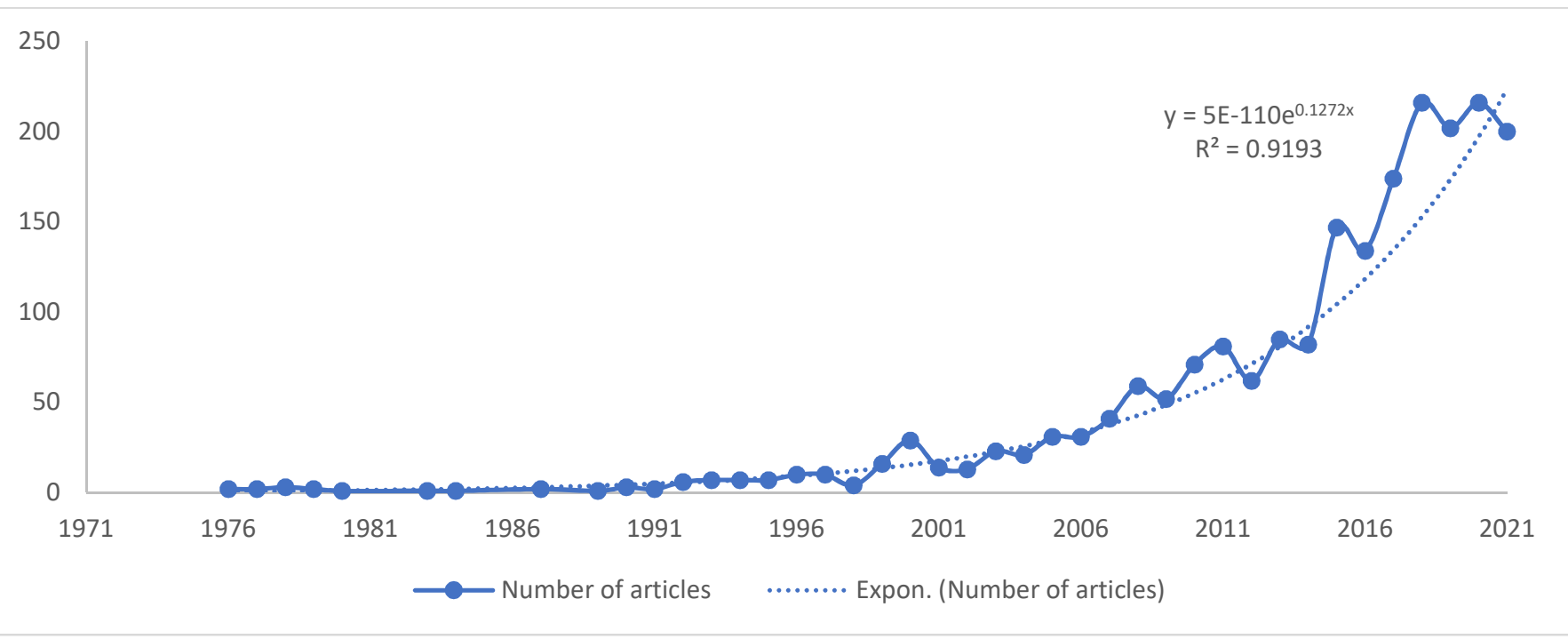

Figure 3. Evolution of the number of publications and exponential variation between periods.

\subsubsection{Subject Area Distribution}

FI can be applied in almost all fields; therefore, theoretical and practical research has been recorded over time in various categories in WoS. After processing the data, a total of 127 WoS categories were obtained, which cover the sample of 2072 documents. To facilitate the completion of this indicator and to highlight the most prolific categories in terms of scientific production, Table 6 presents the 10 main WoS categories with the most published articles on FI and business sustainability. Thus, most documents were published in the categories "Business Economics" ( $n=427)$, "Psychology" $(n=359)$, "Engineering" $(n=350)$, and "Computer Science" ( $n=270)$, which make up $67.85 \%$ of the total scientific production related to FI and business sustainability. It is necessary to mention that the same document might be classified in more than one category, potentially biasing the partial and total data.

Table 6. WOS most published categories.

\begin{tabular}{cccc}
\hline Rank & WOS Categories & Number & Percentage of 2072 \\
\hline 1 & Business Economics & 427 & 20.61 \\
2 & Psychology & 359 & 17.32 \\
3 & Engineering & 350 & 16.89 \\
4 & Computer Science & 270 & 13.03 \\
5 & Science Technology Other Topics & 167 & 8.06 \\
6 & Environmental Sciences Ecology & 150 & 7.24 \\
7 & Social Sciences Other Topics & 70 & 3.38 \\
8 & Telecommunications & 67 & 3.23 \\
9 & Health Care Sciences Services & 59 & 2.85 \\
10 & Public Environmental Occupational Health & 55 & 2.65 \\
\hline
\end{tabular}

When studying the main research domains in which scientific production can be included, six main categories were determined, as shown in Table 7. Most of the papers published in WoS referring to FI and business sustainability focus on "Science Technology": 60.9\% ( $n=1262)$, “Social Sciences": 44.64\% ( $n=925)$, “Technology": $31.71 \%(n=657)$, and "Life Sciences Biomedicine": 25.77\% ( $n=534)$. Fewer publications were included in research domains such as "Physical Sciences": 7.77\% $(n=161)$ and "Art Humanities": $4.1 \%$ 
$(n=85)$. Additionally, in this situation, it is necessary to mention that the same document might be classified in more than one category, potentially influencing partial and total data. The conclusion arising from this is that the topic of FI has been researched in various fields of activity, but mainly in science and technology, which is consistent with the main definition of the concept, namely the development and implementation of ways to reduce the complexity and cost of a product and its manufacture.

Table 7. Research domains of the publications.

\begin{tabular}{cccc}
\hline Rank & Research Domains & $\begin{array}{c}\text { Number of } \\
\text { Publications }\end{array}$ & Percentage of 2072 \\
\hline 1 & Science Technology & 1262 & 60.9 \\
2 & Social Sciences & 925 & 44.64 \\
3 & Technology & 657 & 31.71 \\
4 & Life Sciences Biomedicine & 534 & 25.77 \\
5 & Physical Sciences & 161 & 7.77 \\
6 & Arts Humanities & 85 & 4.1 \\
\hline
\end{tabular}

\subsubsection{Type of Scientific Production}

Regarding the type of scientific production, following the analysis of the 2072 documents published between 1976 and 2021, it was found that most of them were articles $(69.93 \%)$ or proceedings papers $(18.34 \%)$. The results are shown in Figure 4 . This can be justified by the fact that WoS mainly indexes articles and papers presented at conferences, some of which are printed in the form of book chapters, and fewer books [33]. Additionally, the editorial materials mostly include calls for papers for journal special issues dedicated to FI or business sustainability, which reveals the increased interest in research in this field.

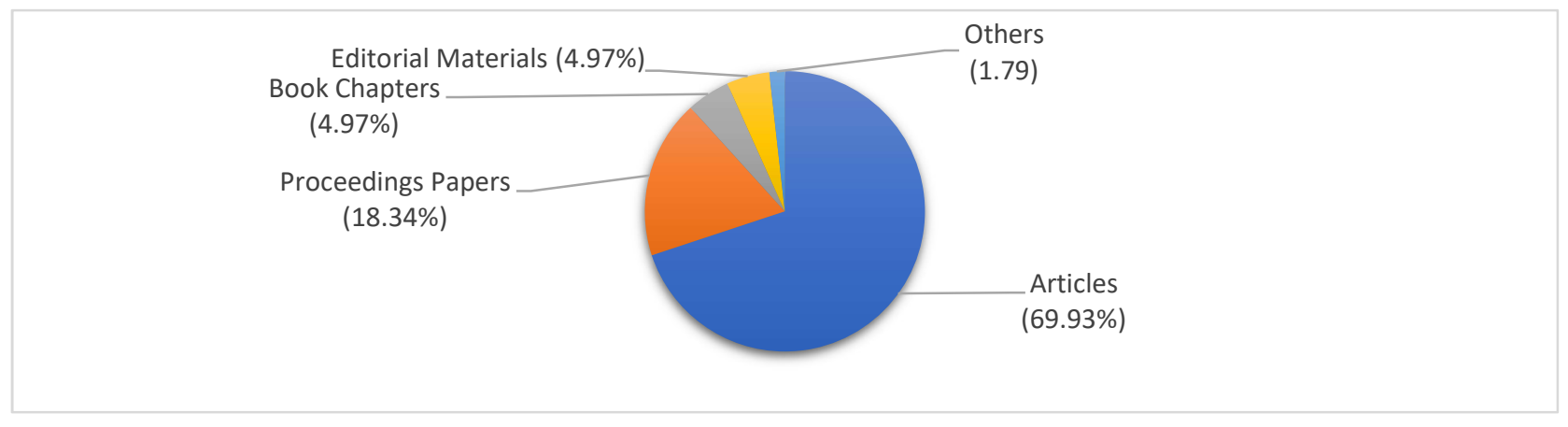

Figure 4. Documents by type.

\subsubsection{Author Productivity}

According to the information analysed from WoS, 4841 authors published at least one paper on the documented topic, and Table 8 shows the 10 most productive researchers in the field of FI and business sustainability knowledge between 1976 and 2021. It is worth noting that all of the authors with the highest scientific production in this field are of European origin. There are seven German authors, one author from the UK, one from Spain, and one from Switzerland who published more than 16 papers on FI and business sustainability and are considered prolific authors. The h-index included in the table was calculated by summing the " $h$ " number of publications with the " $h$ " number of citations. The most productive author is Gigerenzer Gerd, affiliated to Max Planck Institute for Human Development (MPIHD) in Germany, with 45 publications, followed by Bhatti Yasser Ahmad, affiliated to the Said Business School, Oxford, UK, with 22 publications, and Bröder Arndt, from Universität Mannheim, Germany, who also has 22 publications. These authors are prominent scholars in the field of FI and business sustainability research, 
delivering cutting-edge research publications that significantly advance the understanding of researchers and practitioners.

Table 8. Top 10 Prolific Authors.

\begin{tabular}{|c|c|c|c|c|c|c|}
\hline Rank & Author & $\mathbf{P}$ & $\%$ & Affiliation & Country & H-Index \\
\hline 1 & Gigerenzer, Gerd & 45 & 2.17 & MPIHD & Germany & 119 \\
\hline 2 & Bhatti, Yasser Ahmad & 22 & 1.06 & Said Business School, Oxford & UK & 15 \\
\hline 3 & Bröder, Arndt & 22 & 1.06 & Universität Mannheim & Germany & 35 \\
\hline 4 & Herstatt, Cornelius & 21 & 1.01 & Technische Universität Hamburg & Germany & 53 \\
\hline 5 & Pachur, Thorsten & 21 & 1.01 & MPIHD & Germany & 35 \\
\hline 6 & Garcia-Retamero, Rocio & 20 & 0.96 & University of Granada & Spain & $\mathrm{N} / \mathrm{A}$ \\
\hline 7 & Hilbig, Benajamin E. & 20 & 0.96 & University of Koblenz-Landau & Germany & 45 \\
\hline 8 & Glöckner, Andreas & 17 & 0.82 & University of Cologne & Germany & 40 \\
\hline 9 & Hoffrage, Ulrich & 16 & 0.77 & University of Lausanne & Switzerland & 39 \\
\hline 10 & Pohl, Rüdiger F. & 16 & 0.77 & Universität Mannheim & Germany & $\mathrm{N} / \mathrm{A}$ \\
\hline
\end{tabular}

$\mathrm{P}=$ number of publications; \% = percentage of 2072 .

\subsubsection{Regional Distribution of Scientific Production}

Table 9 presents the most prominent countries/regions ranked by documents and citations. The main countries that generated the highest scientific output related to FI and business sustainability are the USA ( $n=589,28.43 \%$ of the total), Germany ( $n=375,18.10 \%$ of the total), England ( $n=222,10.71 \%$ of the total), India $(n=190,9.17 \%$ of the total), China ( $n=109,5.26 \%$ of the total), and France $(n=108,5.21 \%$ of the total). It should be noted that the first three states provide more than $50 \%$ of the total scientific output on the analysed topic, and 87 of the 2072 documents included in the analysed sample do not contain data in this field. Regarding the number of citations, the most prominent states are Germany $(n=12,022)$, the USA $(n=11,371)$, and England $(n=4265)$.

Table 9. WOS—country/region of publication.

\begin{tabular}{clccclcc}
\hline Rank & $\begin{array}{c}\text { Country/Region } \\
\text { by Documents }\end{array}$ & Documents & \% of 2072 & Rank & $\begin{array}{c}\text { Country/Region } \\
\text { by Citations }\end{array}$ & Citations & $\begin{array}{c}\text { Total Link } \\
\text { Strength }\end{array}$ \\
\hline 1 & USA & 589 & 28.43 & 1 & Germany & 12,022 & 5111 \\
2 & Germany & 375 & 18.10 & 2 & USA & 11,371 & 3488 \\
3 & England & 222 & 10.71 & 3 & England & 4265 & 2202 \\
4 & India & 190 & 9.17 & 4 & Switzerland & 3308 & 2737 \\
5 & China & 109 & 5.26 & 5 & Canada & 1528 & 749 \\
6 & France & 108 & 5.21 & 6 & Australia & 1506 & 1263 \\
7 & Canada & 95 & 4.59 & 7 & India & 1248 & 482 \\
8 & Switzerland & 90 & 4.34 & 8 & Spain & 1210 & 499 \\
9 & Netherlands & 84 & 4.05 & 9 & Finland & 1064 & 692 \\
10 & Australia & 83 & 4.01 & 10 & Netherlands & \\
\hline
\end{tabular}

Source: synthesis of authors based on information from WoS and data processing in VOSviewer.

\subsubsection{Research Entities and Funding Agencies}

The amount and quality of the innovations created by global organizations from emerging markets are increasing. In emerging economies, FIs have generated vast demand. FI encourages firms to respond to resource restrictions, whether economic, material or institutional, by transforming these limits into new business models, making alternative solutions available. Research and development are important components in the FI process. Therefore, the countries whose research centres invest in this field of interest have good results in the development of low-cost, simple, and sustainable products that offer basic quality that are subsequently produced and marketed either in the country where they were developed or in emerging economies. Table 10 shows the top 10 research entities with at least 20 affiliated authors. Most of the research entities included in the ranking presented 
come from Germany (three research entities) and the UK and Switzerland (two research entities each). Entities from the USA, India, and France are also included.

Table 10. Top 10 research entities with at least 20 affiliated authors.

\begin{tabular}{clccc}
\hline \multirow{2}{*}{ Rank } & \multicolumn{1}{c}{ Research Entity } & Country & Number & $\begin{array}{c}\text { \% of } \\
\mathbf{2 0 7 2}\end{array}$ \\
\cline { 3 - 5 } & Max Planck Society & Germany & 159 & 7.67 \\
2 & University of California System & USA & 52 & 2.51 \\
3 & Indian Institute of Technology System IIT System & India & 48 & 2.32 \\
4 & University of Mannheim & Germany & 42 & 2.03 \\
5 & University of London & UK & 41 & 1.98 \\
6 & Centre National de la Recherche Scientifique & France & 39 & 1.88 \\
7 & University of Basel & Switzerland & 28 & 1.35 \\
8 & Hamburg University of Technology & Germany & 27 & 1.3 \\
9 & University of Lausanne & Switzerland & 27 & 1.3 \\
10 & University of Oxford & UK & 24 & 1.16 \\
\hline
\end{tabular}

The most prolific research entities in terms of the number of publications are the Max Planck Society of Germany, an affiliation with 159 papers published $(7.674 \%$ of the total sample), The University of California System in the USA, with 52 published papers (2.51\%), and the Indian Institute of Technology System IIT System in India, with 48 published papers $(2.31 \%)$. It is important to note that 88 records $(4.247 \%)$ do not contain data in the field that was being analysed.

Funding is very important in the research and development process, so the allocation of funds to the FI development process is an advantage for agencies and countries that financially stimulate this field. Table 11 presents the most productive funding agencies, who have at least 10 affiliated authors in terms of a number of published research related to FI and business sustainability. The most productive funding agencies come from the USA and UK. The ranking also includes a funding agency from the EU, China, Germany, Canada, and India. Although 1401 records (67.616\%) do not contain data in the analysed field, the most productive funding agencies in terms of the number of papers published are the US National Science Foundation with 58 publications $(2.8 \%)$, The European Commission from the EU with 44 publications (2.12\%), and the National Natural Science Foundation of China with 42 publications $(2.02 \%)$.

Table 11. Funding agencies with at least 10 affiliated authors.

\begin{tabular}{clccc}
\hline Rank & \multicolumn{1}{c}{ Funding Agencies } & Country & Number & \% of 2072 \\
\hline 1 & National Science Foundation & USA & 58 & 2.8 \\
2 & European Commission & EU & 44 & 2.12 \\
3 & National Natural Science Foundation of China & China & 42 & 2.02 \\
4 & United States Department of Health & USA & 40 & 1.93 \\
5 & Human Services & USA & 39 & 1.88 \\
6 & Gational Institutes of Health & Germany & 33 & 1.59 \\
7 & UK Research Innovation & UK & 25 & 1.2 \\
8 & Natural Sciences and Engineering Research & Canada & 14 & 0.68 \\
9 & Council of Canada & UK & 12 & 0.58 \\
10 & Engineering Physical Sciences Research Council & India & 11 & 0.53 \\
\hline
\end{tabular}

\subsubsection{Sources (Journals)}

As presented in Table 9, we analysed the most prolific publication sources in terms of the number of documents and number of citations, both journals and books that include research on FI and business sustainability. It can be seen that the Judgment and Decision Making journal is the leader in the number of published articles $(n=45)$ on the investigated 
topic, representing $2.17 \%$ of the total sample, followed by the journal Sustainability journal with $1.5 \%(n=31)$ and the Journal of Behavioral Decision Making with $1.3 \%$ of the sample $(n=27)$. It should be noted that there was found no journal dedicated exclusively to this topic, with most journals only having one or two articles that address this topic. As per our analysis, we found a total of 1480 sources, mostly conference proceedings, of which only 65 have more than 5 papers published on the investigated research topic. There is a need for dedicated publications that can stimulate researchers to publish results at a faster pace and that can attract funding for this research niche.

Table 12 also indicates the discrepancy between the most prominent publication sources in terms of the number of documents and the number of citations. The most cited journal for documents related to the investigated topic is Psychological Review, with 3681 citations and a total link strength of 524, as calculated in VOSViewer. This is followed by the journal Judgment and Decision Making, which comprises 1090 citations and a total link strength of 654, and the Journal of Experimental Psychology Learning, which contains 1073 citations and a total link strength of 499 . There is a preponderance of citations in journals that focus on the psychological component and consumer behaviour, and this is to the detriment of citations in journals in the business, technology, or science categories.

Table 12. Most prominent sources by the number of documents and citations.

\begin{tabular}{|c|c|c|c|c|c|c|c|}
\hline $\mathbf{R}$ & Source by Documents & $\mathbf{D}$ & $\%$ & $\mathbf{R}$ & Source by Citations & $\mathrm{C}$ & TLS \\
\hline 1 & Judgment and Decision Making & 45 & 2.17 & 1 & Psychological Review & 3681 & 524 \\
\hline 2 & Sustainability & 31 & 1.5 & 2 & Judgment and Decision Making & 1090 & 654 \\
\hline 3 & Journal of Behavioral Decision Making & 27 & 1.3 & 3 & $\begin{array}{c}\text { Journal of Experimental Psychology } \\
\text { Learning Memory and Cognition }\end{array}$ & 1073 & 499 \\
\hline 4 & India Studies in Business and Economics & 25 & 1.21 & 4 & Bioinformatics & 992 & 0 \\
\hline 5 & Globalization and Health & 24 & 1.16 & 5 & Journal of Behavioral Decision Making & 899 & 483 \\
\hline 6 & Journal of Cleaner Production & 20 & 0.97 & 6 & Psychonomic Bulletin E Review & 625 & 325 \\
\hline 7 & $\begin{array}{l}\text { Journal of Experimental Psychology } \\
\text { Learning Memory and Cognition }\end{array}$ & 18 & 0.87 & 7 & Research-Technology Management & 461 & 165 \\
\hline 8 & Behavioral and Brain Sciences & 16 & 0.77 & 8 & $\begin{array}{c}\text { Organizational Behavior and Human } \\
\text { Decision Processes }\end{array}$ & 437 & 123 \\
\hline 9 & Lecture Notes in Computer Science & 16 & 0.77 & 9 & Journal of Cleaner Production & 434 & 174 \\
\hline 10 & Frugal Innovation Models Means Methods & 15 & 0.72 & 10 & Globalization and Health & 416 & 20 \\
\hline
\end{tabular}

$\mathrm{R}=$ rank; $\mathrm{D}=$ number of documents; $\%$ = percentage of 2072; $\mathrm{C}=$ number of citations; TLS = total link strength.

\subsection{Performance Analysis (Citation Analysis)}

Figure 5 presents the annual evolution of the number of citations reported in WoS publications on this topic, which was generated from the sample of 2072 documents. A total of 23,790 citations has been recorded since 1985. The number of citations has risen exponentially, which is consistent with the number of publications previously presented. The number of citations reached a peak in 2021, with 3456 citations. As a result, both related indicators: annual scientific production and citation analysis, reveal significant growth in international interest and scientific production, indicating that FI and business sustainability represent a rising line of inquiry at the start of the twenty-first century for.

\subsection{Science Mapping}

\subsubsection{Conceptual Structure: Co-Word Analysis}

The most commonly used keywords were extracted and examined to categorize the 2072 documents in the sample. The topics that appear the most frequently in the area under study stand out as a result of this analysis. From the 2072 articles, 7785 keywords were identified. Of these, 6207 words appeared only once, resulting in a $79.73 \%$ prevalence. Table 13 presents the 10 most frequently utilized keywords in the analysed documents. As expected, the most common keywords used by authors are "frugal", with 256 occurrences, and "frugal innovation", with 210 occurrences. Other very transversal concepts are "models" (164 occurrences) and "decision-making" (143 occurrences). 


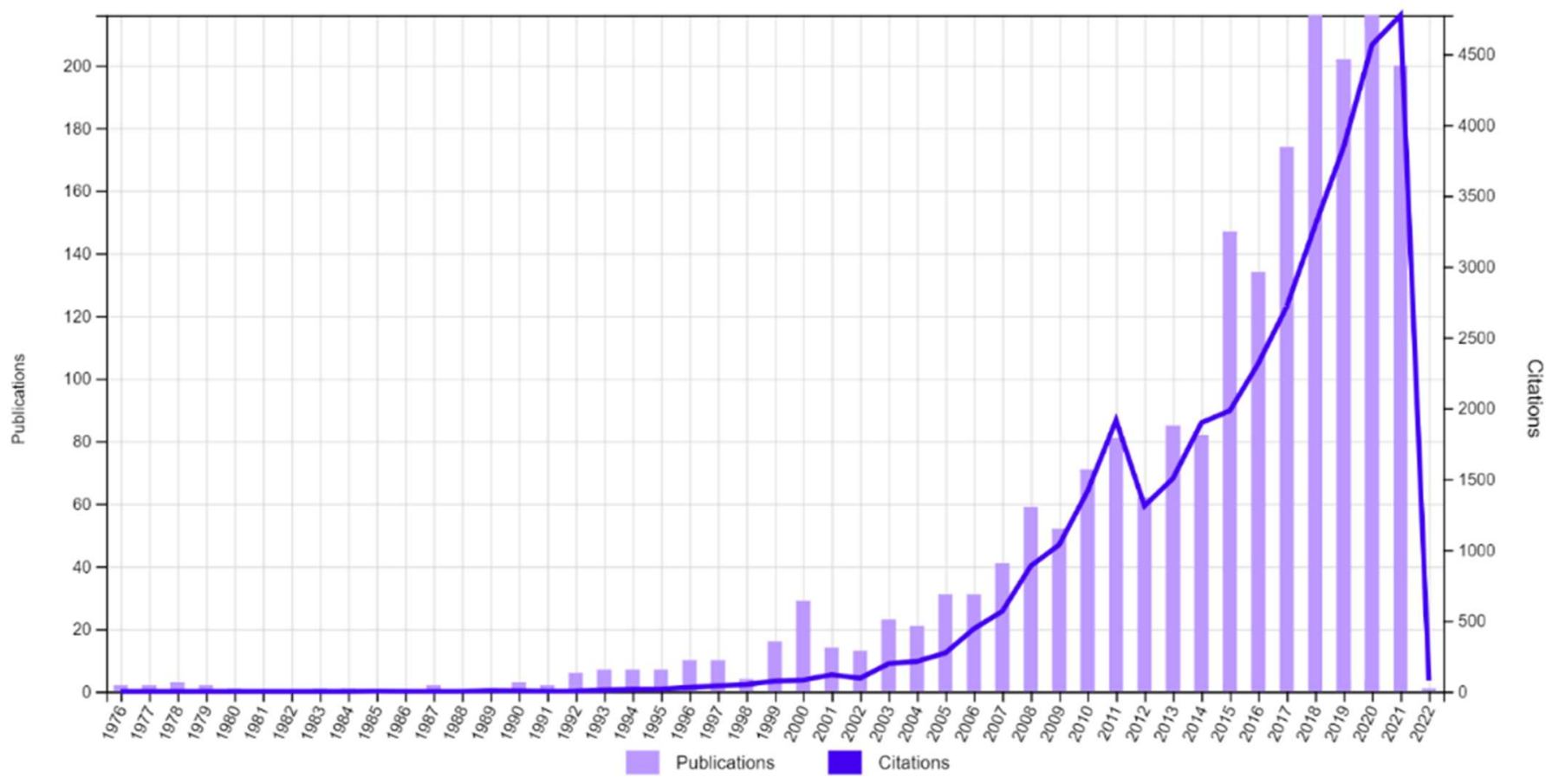

Figure 5. WOS—citation analysis.

Table 13. Occurrence of author keyword.

\begin{tabular}{clcc}
\hline Rank & Keyword & Occurrences & Total Link Strength \\
\hline 1 & frugal & 256 & 1159 \\
2 & frugal innovation & 210 & 563 \\
3 & models & 164 & 744 \\
4 & decision-making & 143 & 813 \\
5 & heuristics & 128 & 623 \\
6 & reverse innovation & 115 & 353 \\
7 & information & 109 & 588 \\
8 & emerging markets & 94 & 398 \\
9 & judgement & 90 & 483 \\
10 & choice & 85 & 471 \\
\hline
\end{tabular}

Source: authors' elaboration based on VOSviewer analysis.

Figure 6 depicts a network visualization map based on co-occurrence terms. Full counting was selected, and for proper visualization of the results, the minimum number of occurrences was set at 15 keywords. The map divides the keywords into three clusters (red, green, blue), generating 2253 links with a total link strength of 9476.

Table 14 presents the analysis of the three clusters previously identified. The bestrepresented one is the red cluster, counting 49 items related to business and sustainability. Some of the most common terms included in this cluster are "business models", "challenges", "frugal innovation", "management", "performance", "sustainability", "strategies", and "sustainable development". The green cluster focuses on strategic thinking and brings together, among others, the following keywords: "decision making", "ecological rationality", "judgement", "models", and "strategy selection". Finally, the third cluster (blue) refers to consumption behaviour. This research line uses as main keywords: "behaviour, consumption", "decision", "risk", "uncertainty", and "values". 


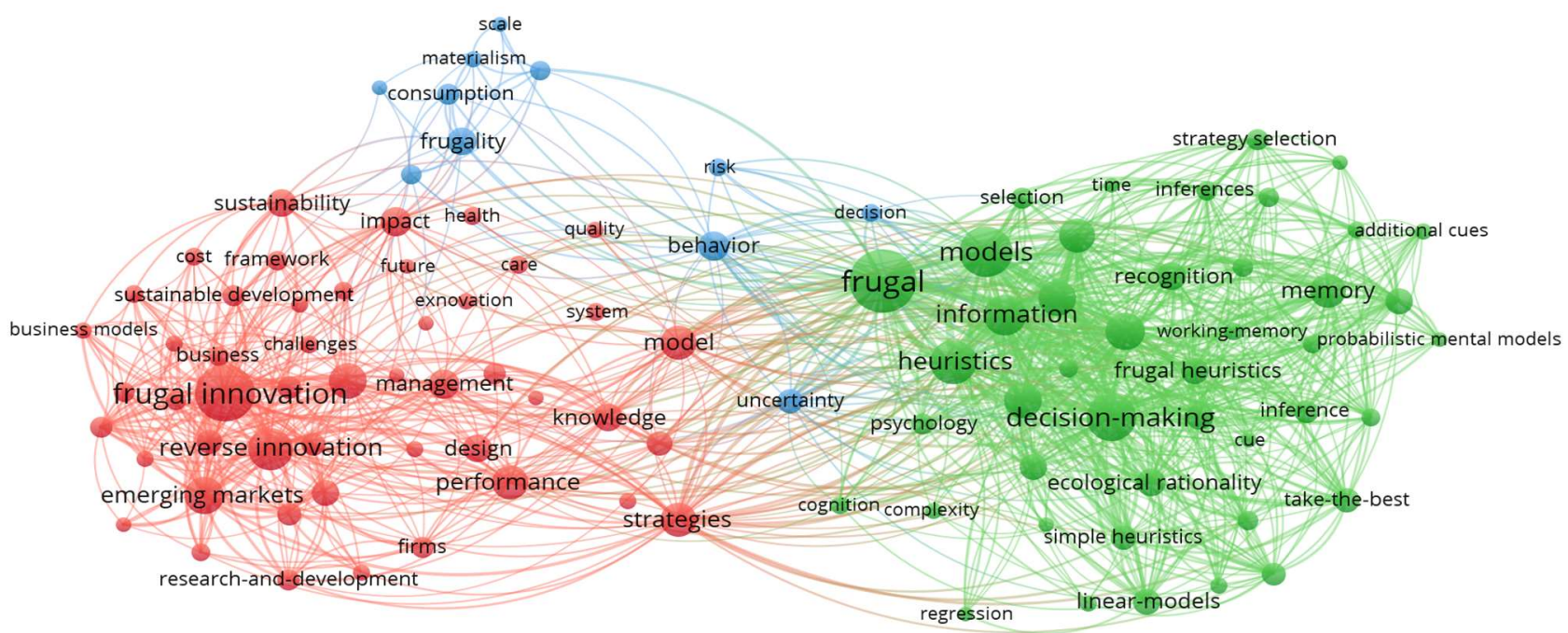

Figure 6. Network visualization map based on text data-term co-occurrence.

Table 14. Author keyword clusters.

\begin{tabular}{|c|c|c|c|}
\hline Cluster & Number of Items & Research Area & Main Keywords \\
\hline Cluster 1 (red) & 49 items & Business sustainability & $\begin{array}{l}\text { Business models, challenges, disruptive innovation, } \\
\text { emerging markets, FI, impact, knowledge, } \\
\text { management, performance, reverse innovation, } \\
\text { sustainability, strategies, sustainable development } \\
\text { Decision making, ecological rationality, frugal, }\end{array}$ \\
\hline Cluster 2 (green) & 44 items & Strategic thinking & $\begin{array}{c}\text { heuristics, information, judgement, models, memory, } \\
\text { strategy selection }\end{array}$ \\
\hline Cluster 3 (blue) & 11 items & Consumption behaviour & $\begin{array}{l}\text { Behaviour, consumption, decision, risk, } \\
\text { uncertainty, values }\end{array}$ \\
\hline
\end{tabular}

Figure 7 presents the evolution of the visualization map based on co-occurrence terms. It can be seen that clusters 1 and 3 integrate more recent concerns of specialists in the field, concentrating keywords that are found in publications published after 2016. Cluster 2, the one related to strategic thinking, specifically includes keywords from publications from 2010 to 2014 that are not found in research published in the last five years. The trend towards the analysis of business sustainability and consumer behaviour in the context of FIs is noted.

\subsubsection{Intellectual Structure: Co-Citation Analysis}

When two documents cite the same document, bibliographic coupling occurs, which might illustrate the strength of a given publication in comparison to a collection of other publications. This method is applicable to documents, journals, authors, institutions, and countries. It is possible to see which publications and authors are associated through multiple citations by analysing the bibliographic coupling of contributors.

We performed a co-authorship analysis using the VOSviewer software to investigate the most-cited researchers and to illustrate the bibliographic coupling between them as well as the countries and institutions that they are affiliated to. Since it identifies the significant publications in the research area, the analysis of article citations is the most extensively used way of assessing the influence of authors, journals, and publications. Figure 8 illustrates 
the network visualization map based on co-citation analysis, including the 32 most cited authors grouped in 3 clusters, with 361 links and a total link strength of 4565 .

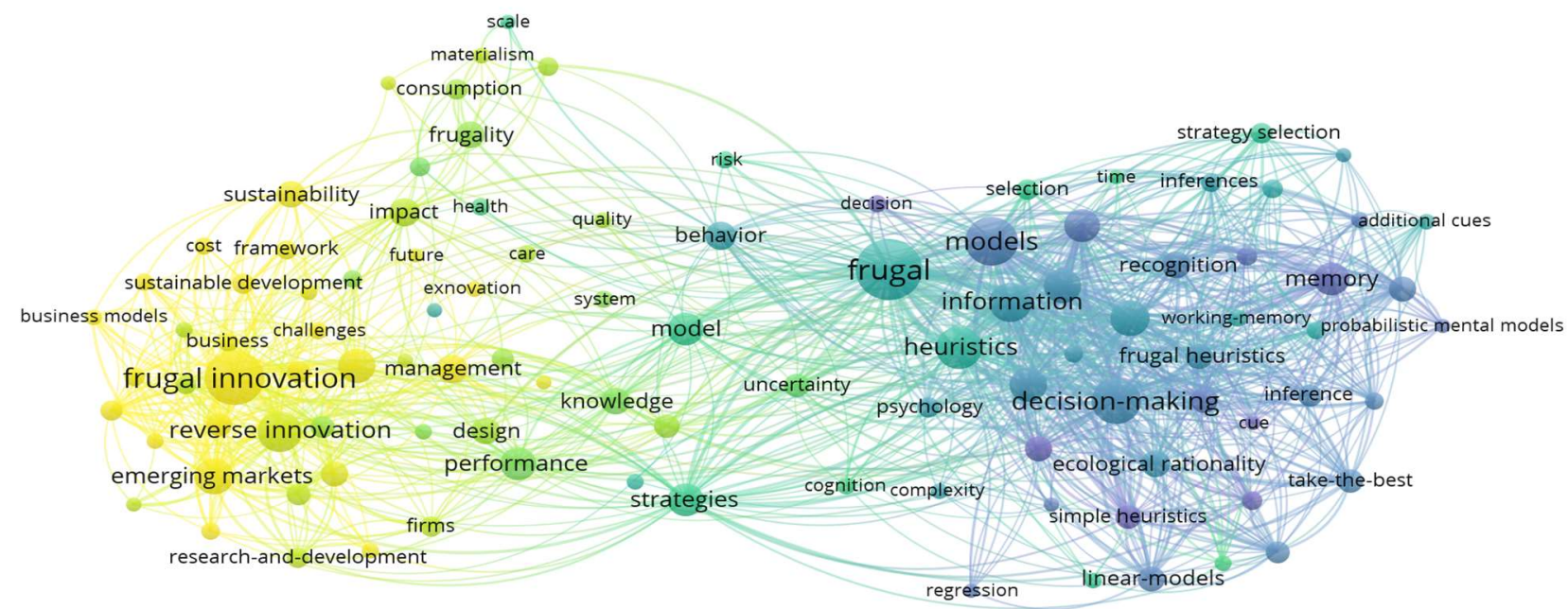

$\begin{array}{lllll}2010 & 2012 & 2014 & 2016 & 2018\end{array}$

Figure 7. Network visualization map based on evolution text data-term co-occurrence.

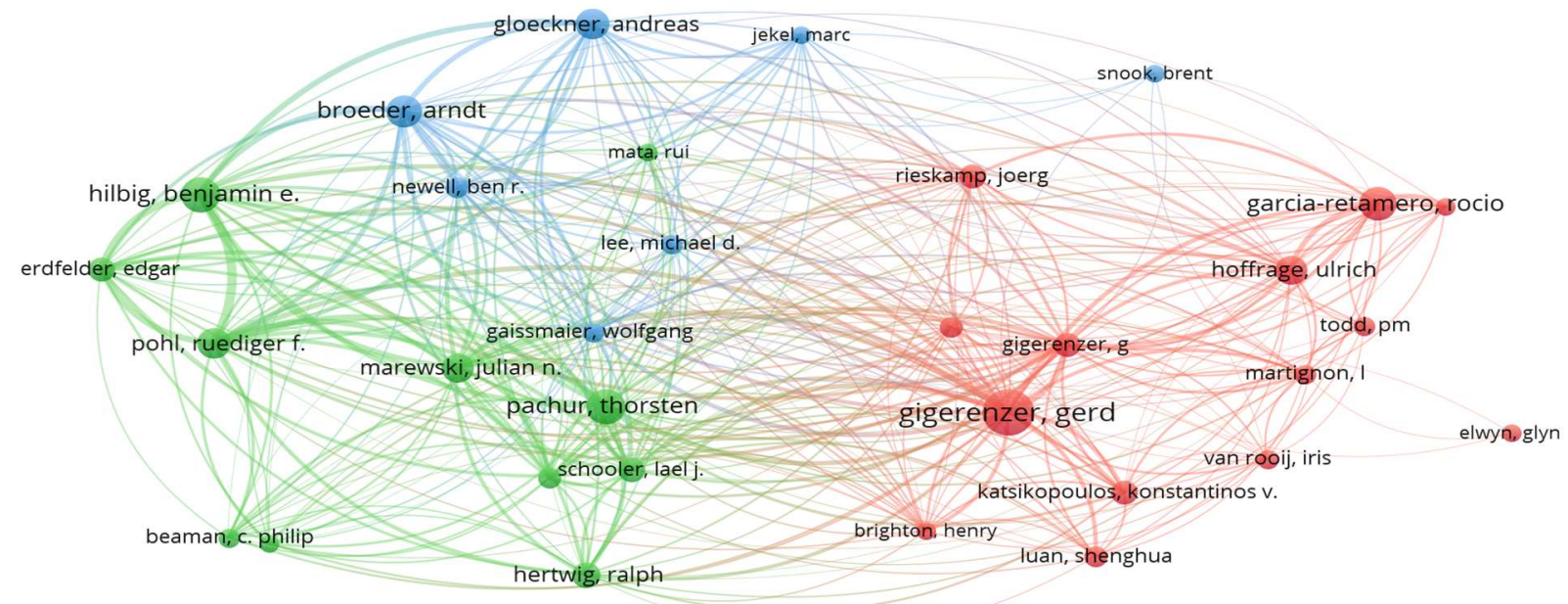

Figure 8. Network visualization map based on co-citation analysis.

Based on Table 15, the most influential author, in terms of the number of citations, is Gigerenzer Gerd $(n=7187)$ from the Max Planck Institute for Human Development, Germany. The second most cited author is also of German origin: Gaissmaier Wolfgang $(n=1595)$, from the University of Konstanz. Similar to the case of author productivity, the majority of the most cited authors are from Germany $(n=8)$, with the other two being affiliated with research entities from the Netherlands and USA. 
Table 15. Most cited Authors.

\begin{tabular}{ccccccc}
\hline Rank & Author & C & P & Affiliation & Country & H-Index \\
\hline 1 & Gigerenzer, Gerd & 7187 & 45 & MPIHD & Germany & 119 \\
2 & Gaissmaier, Wolfgang & 1,595 & 6 & University of Konstanz & Germany & 32 \\
3 & Brighton, Henry & 790 & 5 & Tilburg University & Netherlands & Germany \\
4 & Pachur, Thorsten & 649 & 21 & MPIHD & USA & 35 \\
5 & Schooler, Lael J. & 649 & 10 & Syracuse University & Germany & 45 \\
6 & Hilbig, Benajamin E. & 608 & 20 & University of Koblenz-Landau & Germany & 35 \\
7 & Bröder, Arndt & 567 & 17 & Universität Mannheim & Germany & 71 \\
8 & Hertwig, Ralph & 527 & 11 & MPIHD & Germany & G/A \\
9 & Pohl, Rüdiger F. & 469 & 15 & Universität Mannheim & 40 \\
10 & Gloeckner, Andreas & 457 & 15 & University of Cologne & & \\
\hline
\end{tabular}

$\mathrm{C}=$ number of citations, $\mathrm{P}=$ number of publications.

\subsubsection{Social Structure: Co-Author Analysis}

Based on co-authorship analysis, Figure 9 depicts the collaboration map between the prominent authors who have published their research on FI and business sustainability. The colours represent the working groups, and the size of the circle reflects the number of documents authored by each researcher. The network is decentralized, which may support the quick growth of the study topic because there are 24 authors with a minimum of five documents published who appear to have 6 stable international research networks among the most productive writers, generating 57 links with a total link strength of 138 .

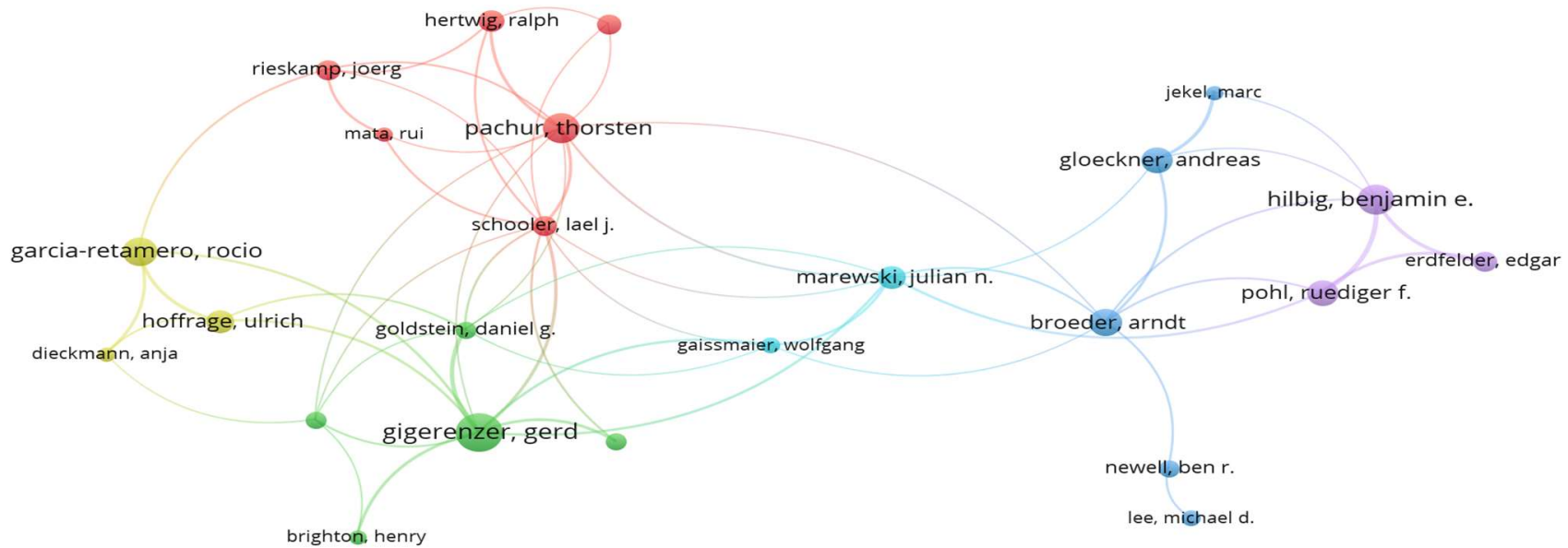

Figure 9. Network visualization map of the co-authorship.

Moreover, to explore the research collaboration between various countries, a country collaboration network graph is presented in Figure 10. This aims to show the most fruitful international collaborations. The network visualization map was generated in VOSviewer by applying the following restrictions: the maximum number of countries per document was set at 25 , the minimum number of documents of a country was set at 5 , and the selected counting method was fully counted. Out of 96 countries, 53 met the thresholds and were grouped in 9 clusters, creating 663 links and obtaining a total link strength of 11,703 . The most highly active countries on this subject are the USA, Germany, England, the Netherlands, and India, with major collaborations across the globe. Contributions from Ireland, Serbia, and Hungary were found to be scanty. 


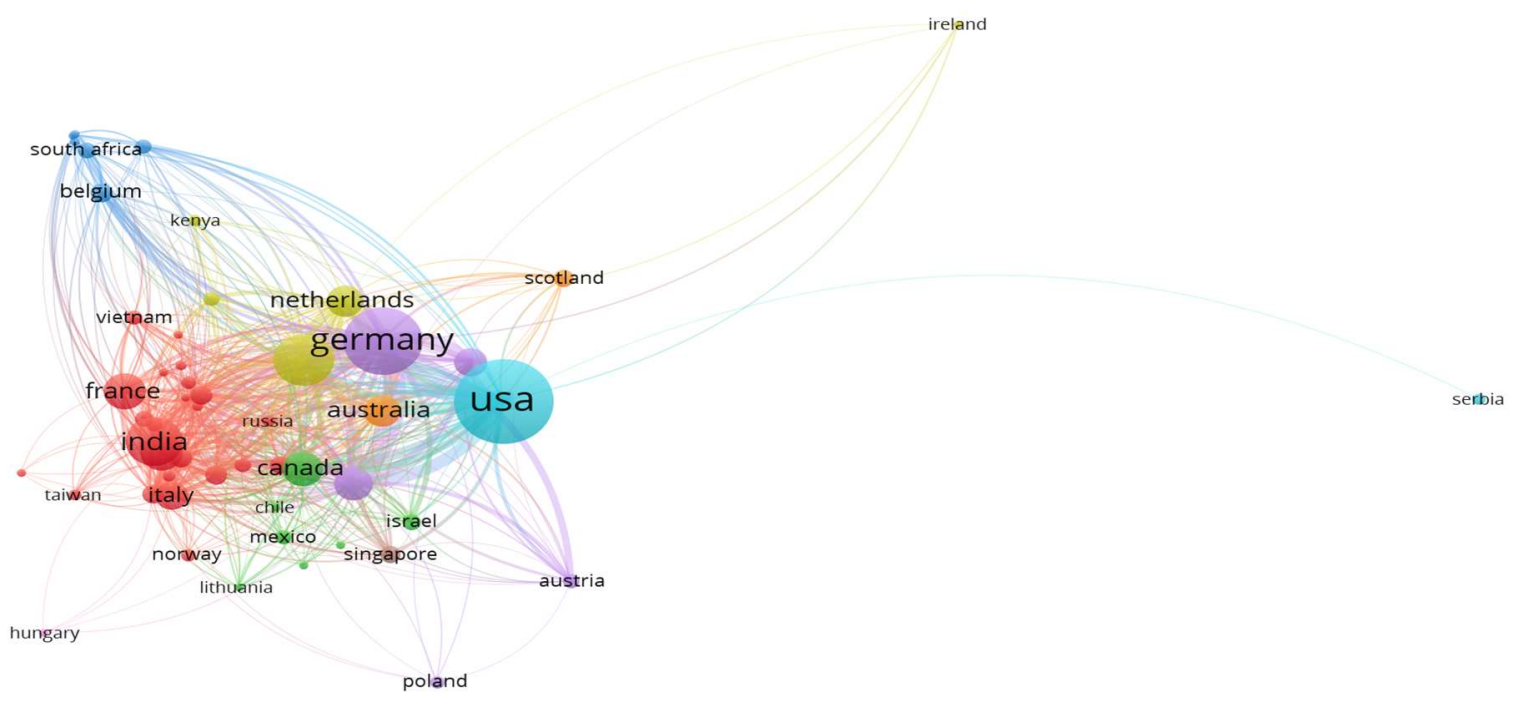

\& VOSviewer

Figure 10. Network visualization map of the co-authorship countries.

Figure 11 presents the network visualization map of the co-authorship institutions, which was developed using the VOSviewer software and illustrates the main research entities that published documents on this issue as well as collaboration between the organizations. The visualization was created using the sample of 2072 articles from this study by applying the following restrictions: maximum number of countries per document: 25 , the minimum number of documents of an organization: 5, and full counting was selected as the counting method. Out of 1895 organizations, 141 met the thresholds, were grouped in 15 clusters, creating 251 links and obtaining a total link strength of 380. The Max Planck Society stands out in the WoS results as well as the University of California System and Indian Institute of Technology System IIT System.

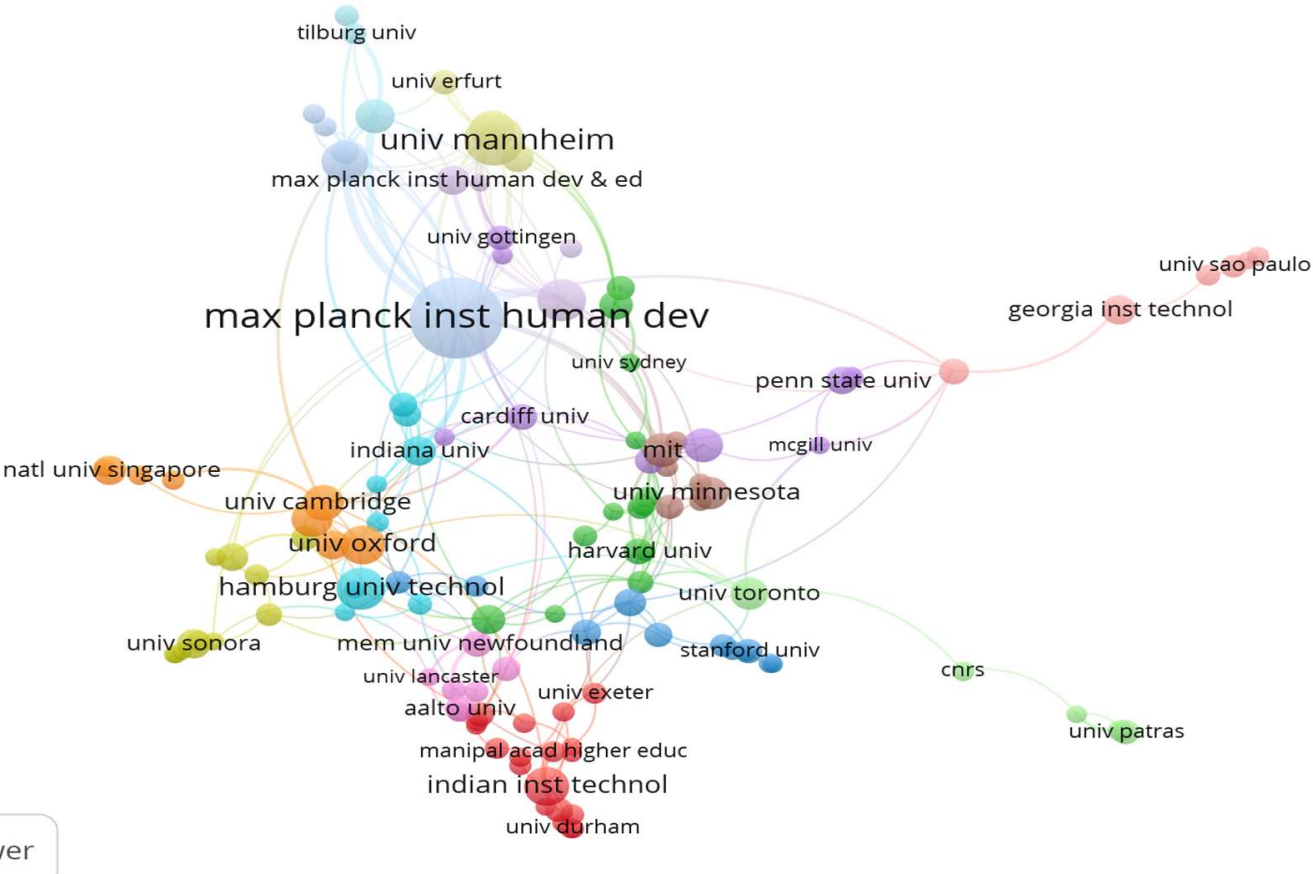

Figure 11. Network visualization map of the co-authorship institutions. 


\section{Discussion}

This bibliometric study used statistical tools to examine a substantial amount of scientific production to determine patterns and citations and/or co-citations of business sustainability and FI, per year, country, publisher, author, and research challenge [162]. VoSViewer software was used to construct the graphical bibliometric examination.

The current research paper explored the practical and theoretical connections among sustainability, sustainable development, and frugality. Although there is no consensus regarding the relationship between FI and sustainability in the literature, most papers find a positive connection between the two concepts. The concept of sustainability is complex and is still debated and contested [45].

One major strength of FI is that it can also provide chances for inclusive growth by allowing local enterprises to innovate to attract a large number of prospective clients from a microeconomic level. Another important strength would represent the fact that FI is expected to be a key engine of industrial growth, and maybe of inclusive growth, and it has the potential to open a previously underserved area of innovation in both developing and mature economies.

However, a significant weakness is that innovation theories have not fully debated whether frugal innovation is always preceded by technological newness, architectural modifications, the establishment of new markets, or the disruption of existing enterprises.

Several key conclusions emerge from a survey of the literature on the convergence of frugal innovation and sustainable development. Frugal innovations or local businesses have the ability to provide low-income individuals with affordable access to key items and services while also addressing labour market inequalities. Furthermore, frugal innovations can help to build isolated communities in underdeveloped nations by bringing in localized, basic, and easy-to-maintain solutions.

The current study aimed to address the topic of FI and business sustainability through science mapping and bibliometric analysis. To reach our objective, the paper intended to map the literature by narrowing its research topics and identifying certain patterns. For this purpose, the article investigated the WoS database on FI and business sustainability, generating a sample of 2072 documents published between 1976-2021. Aiming to provide scholars with a quantified and graphic representation of the FI and business sustainability field by covering the publications in this field, the VOSviewer software was used to perform a science mapping of the conceptual, intellectual, and social structure.

Research on FI linked to business sustainability has shown a positive trend throughout the years, with one considerable increase starting from 2000 and another one from 2015. Throughout the last six-year people (2016-2021), the interest that researchers have had regarding the relationship between FI and business sustainability was very high, and the number of citations tripled compared to in the previous period, 2011-2015. This can be justified by the growing number of products included in the FI category that have been launched on the market in the last decade, a finding based on previous research and studies. Additionally, this increase is related to the economic crisis in 2007-2008, which resulted in countries finding solutions to develop FI at a faster pace. Both related indicators: annual scientific production and citation analysis, reveal significant growth in international interest and scientific production, indicating that it is a growing line of inquiry at the start of the twenty-first century for FI and business sustainability.

FI can be applied in almost all fields; therefore, theoretical and practical research has been recorded over time in various research areas. Most of the papers published in WoS referring to the FI and business sustainability focus on "Science Technology", "Social Sciences", "Technology", and "Life Sciences Biomedicine". The topic of FI has been researched in various fields of activity, but mainly in science and technology, which is consistent with the main definition of the concept, namely the development and implementation of ways to reduce the complexity and cost of the product and its manufacture.

Most of the scientific production are articles (69.93\%) or proceedings papers (18.34\%). A total of 4841 different authors published at least one paper on the documented topic. It 
was revealed that all of the authors with the highest scientific production in this field are of European origin, namely from Germany, the UK, Spain, and Switzerland. These authors are prominent scholars in the field of FI and business sustainability research, delivering cuttingedge research publications that significantly advance the understanding of researchers and practitioners. The most productive and most cited author is Gigerenzer Gerd, who is affiliated with MPIHD in Germany.

Research and development are important components in the FI process. Therefore, the countries whose research centres invest in this field of interest have good results in the development of low-cost, simple, and sustainable products that offer the basic quality that they subsequently produce and market either in the country where they were developed or in emerging economies. The research entities with the highest number of publications come from the USA, Germany, UK, Switzerland, India, France, and Australia. The most prolific research entities in terms of the number of publications are the Max Planck Society of Germany, an affiliation with 159 papers published, The University of California System in the USA, with 52 published papers, and the Indian Institute of Technology System IIT System of India, with 48 published papers.

Funding is very important in the research and development process, so the allocation of funds to the FI development process is an advantage for agencies and countries that financially stimulate this field. The most productive funding agencies in terms of the number of published research come from the USA, UK, the EU, China, and Germany.

Regarding the most prolific publication sources, we found a total of 1480 sources, mostly conference proceedings, of which only 65 have more than 5 papers published on the investigated research topic. Additionally, there is no journal that is dedicated exclusively to this topic, with most journals having only one or two articles that address this topic. There is a need for dedicated publications that can stimulate researchers to publish the results at a faster pace and that can attract funding for this research niche.

The most commonly used keywords used by authors can be grouped into three clusters (Cluster 1-business sustainability; Cluster 2-strategic thinking; Cluster 3-consumption behaviour). It was revealed that clusters 1 and 3 integrate more recent concerns, concentrating on keywords that were found in publications published after 2016. Cluster 2 specifically includes keywords from publications from 2010 to 2014, which are not found in research published in the last five years. The trend towards the analysis of business sustainability and consumer behaviour in the context of FIs is noted.

The co-authorship analysis revealed that the majority of the most cited authors are from Germany. The most highly active countries on the subject of FI and business sustainability are the USA, Germany, England, the Netherlands and India, with major collaborations across the globe. Contributions from Ireland, Serbia, and Hungary were found to be scanty. The Max Planck Society, University of California System, and Indian Institute of Technology System IIT System are the research entities who have developed the most powerful collaboration between organizations.

According to the findings of the co-citation analysis, FIs have been viewed as a disruptive phenomenon and have been targeted particularly at low-income consumers and emerging economies. Nevertheless, frugality potential in more economically developed markets is being slowly but surely recognized. The steadily rising body of research and the inclusion of numerous topics titles linked to the phenomena suggest that FIs will assume greater importance in the future.

\subsection{Limitations}

This research presents several limitations that might serve as the foundation for future studies. First of all, even though the science mapping's methodical and quantitative methodology helps to identify the framework of a knowledge corpus, it cannot substitute additional review approaches, such as meta-analysis and qualitative literature review. As a result, the bibliometric review method should be supplemented with complementary review methods that assess the papers' substantive results in the review database. For 
this reason, the goal of this study is to serve as the first step toward a more complete evaluation of the literature on frugality and sustainable business development. Secondly, since knowledge on FI is still in its early research stages, the construct's conceptual limits and boundaries have yet to be developed. Thirdly, this study was focused on scientific documents retrieved from the WoS database. Utilizing other databases, such as Scopus, might generate slightly different results.

Moreover, a huge number of publications attest to frugal innovation and potential consequences for sustainable development without distinguishing between the various typologies of enterprises and initiators. When making theoretical assertions about the influence of frugal innovation on sustainable development, studies sometimes lack a clear viewpoint or distinguish between private sector players. In this regard, it is critical to distinguish between private sector participants in order to increase our knowledge of each group's motives and contributions.

Another limitation of this paper is that it focused on the performance domain when discussing frugal innovation. However, the experience, including the cultural experience, of the customer in appreciating the value of frugal innovations matters.

While some writers claim that frugal innovation would lead to more inclusive forms of innovation and sustainable economic growth, others contend that it will be unable to solve fundamental disparities in the political economy and may even aggravate the capitalist exploitation of low-income areas.

\subsection{Future Research Directions}

From a scholarly point of view, the number of journals that have addressed the issue of frugality is remarkable since this topic is a multi-layered theme of interest in many relevant areas. In fact, these numerous sources of information from various research subjects constitutes opportunities for scientists to find a foundation for their analysis.

In these conditions, future research should continue to investigate the relationship between frugality and other concepts such as corporate social responsibility (CSR), business ethics, and sustainable leadership in order to identify new and innovative research directions.

Secondly, comparative reviews between different types of frugal innovation across business sectors would improve the understanding of frugality to a more extensive viewpoint. Therefore, further analysis should focus on more factual case studies regarding frugal innovation process as well as on their analysis from a critical point of view. With this in mind, upcoming research should illustrate the similarities and differences of FI (strengths and weaknesses) and integrate the results in a novel framework perspective.

Something that is often overlooked is the idea that future research on frugal innovation should not only improve performance but also experience, including the cultural experience of the unserved lower-end customer, and this would contribute to a rich discussion on the advancement of frugal innovation.

Something else that is equally important is the fac that it is unclear as to how to assess the long-term viability of various frugal innovations. Several alternatives have been proposed.

However, the question that rises further is whether the sustainability of FI should be evaluated in comparison to current solutions in the market or according to the most innovative options available.

\section{Conclusions}

A common observation is that in terms of economic sustainability, FI is an appropriate process to cut costs and develop economies in low-income and emerging markets. Secondly, these solutions constitute an opportunity to improve the life quality for customers through the easier access to low-cost and more environmentally friendly products. Therefore, affordability is becoming increasingly vital both for businesses as well as for society. 
In terms of the economic sustainability perspective, modern FI technologies can free up various resources that can be reintroduced into the community's economy. For this reason, frugality is considered to be a strategy for expansion in emerging markets.

In conclusion, FI is an efficient way to achieve long-term growth since it creates new types of jobs, activities, and consumers segments. In addition, frugality empowers local people and public authorities to engage in new business models towards producing non-conventional products that support sustainable development.

Unlike most of previous studies, the current work has a double approach: it identifies the primary theme of FI linked to business development and explores it through science mapping. Towards this objective, this study was designed to explore the horizons of FI and the major correlational areas in the literature through a comprehensive bibliometric analysis.

This extensive bibliometric analysis will aid future scholars in identifying emergent research subjects and potential collaborations. Initially, the paper analysed the perspective of current research on FI and business sustainability. The findings in Section 4 highlighted the focus of the current research, indicating the significant contributions to the area in terms of authors, universities, journals, and countries. The second research question in the paper was addressed in Section 2.3 by delving into the main research methods utilized by researchers to explore FI and business sustainability. Furthermore, to address the third research question about the main research clusters on FI and business sustainability, the key thematic areas were emphasized and were bibliographically clustered into three clusters based on the main study areas relating to these issues. This study also examines the existing and emerging literature on FI using a thematic evolution map to identify the emerging themes. As a result, these themes point the way forward for future research in the area of FI and business sustainability. Research and development teams could use the bibliometric approach to delve into the search query and acquire important publications as reference checkpoints for undertaking cutting-edge research and development.

All in all, the findings from this analysis are useful for researchers who desire to contribute to the field's growth and encourage homogenous and consistent knowledge accumulation.

Author Contributions: Conceptualization, A.D.; methodology, A.D.; software, A.D.; validation, A.-M.B., R.D. and A.-M.P.; formal analysis, A.-M.B.; funding acquisition, I.M.; investigation, R.D. and A.-M.B.; resources, R.D., A.-M.P., C.A.S. and I.M.; writing—original draft preparation, A.D. and A.-M.B.; writing-review and editing, A.D., A.-M.B., R.D., A.-M.P. and C.A.S.; visualization, A.-M.P.; supervision, I.M. All authors have read and agreed to the published version of the manuscript.

Funding: This research received no external funding.

Institutional Review Board Statement: Not applicable.

Informed Consent Statement: Not applicable.

Conflicts of Interest: The authors declare no conflict of interest.

\section{References}

1. $\quad$ Elkington, J. Cannibals with Forks: The Triple Bottom Line of 21st Century Business, 7th ed.; Capstone: Oxford, UK, 1997.

2. Kahle, H.N.; Anna, D.; Ernst, P.; Prabhu, J. The democratizing effects of frugal innovation: Implications for inclusive growth and state-building. J. Indian Bus. Res. 2013, 5, 220-234. [CrossRef]

3. Cai, Q.; Ying, Y.; Liu, Y.; Wu, W. Innovating with Limited Resources: The Antecedents and Consequences of Frugal Innovation. Sustainability 2019, 11, 5789. [CrossRef]

4. Govindarajan, V.; Ramamurti, R. Reverse innovation, emerging markets, and global strategy. Glob. Strateg. J. 2011, 1, 191-205. [CrossRef]

5. The Economist. The Power to Disrupt, 395:8678, pp. 16-18, 2010. Ryder, B. The power to Disrupt, 395(8678), 2010. Available online: https:/ / www.economist.com/special-report/2010/04/17/the-power-to-disrupt (accessed on 20 December 2021).

6. Brem, A.; Ivens, B. Do Frugal and Reverse Innovation Foster Sustainability? Introduction of a Conceptual Framework. J. Technol. Manag. Grow. Econ. 2013, 4, 31-50. [CrossRef]

7. Brown, J.S.; Hegel, J. Innovation blowback: Disruptive management practices from Asia. McKinsey Q. 2005, 1, 35-45. 
8. Auvinet, C.; Lloret, A. Understanding social change through catalytic innovation: Empirical findings in Mexican social entrepreneurship. CJAS 2015, 32, 238-251. [CrossRef]

9. Kumar, N.; Puranam, P. Frugal engineering: An emerging innovation paradigm. Ivey Bus. J. 2012, 76, 14-16. Available online: http://iveybusinessjournal.com/publication/frugal-engineering-an-emerginginnovation-paradigm (accessed on 1 November 2021).

10. Kumar, H.; Bhaduri, S. Jugaad to grassroot innovations: Understanding the landscape of the informal sector innovations in India. Afr. J. Sci. Technol. Innov. Dev. 2014, 6, 13-22. [CrossRef]

11. Rao, B.C. How disruptive is frugal? Technol. Soc. 2013, 35, 65-73. [CrossRef]

12. Gupta, S. Understanding the feasibility and value of grassroots innovation. J. Acad. Mark. Sci. 2019, 48, 941-965. [CrossRef]

13. Nunes, P.F.; Breene, T.S. Jumping the S-Curve. How to Beat the Growth Cycle, Get on Top, and Stay There; Harvard Business School Publishing: Boston, MS, USA, 2011.

14. Winterhalter, S.; Zeschky, M.B.; Neumann, L.; Gassmann, O. Business models for frugal innovation in emerging markets: The case of the medical device and laboratory equipment industry. Technovation 2017, 66, 3-13. [CrossRef]

15. Hossain, M. Mapping the frugal innovation phenomenon. Technol. Soc. 2017, 51, 199-208. [CrossRef]

16. Cornell University; INSEAD; WIPO. The Global Innovation Index 2015: Effective Innovation Policies for Development; Cornell University: Ithaca, NY, USA; INSEAD: Fontainebleau, France; WIPO: Geneva, Switzerland, 2015.

17. Angot, J.; Plé, L. Serving poor people in rich countries: The bottom-of-the-pyramid business model solution. J. Bus. Strategy. 2015, 36, 3-15. [CrossRef]

18. Basu, R.R.; Banerjee, P.M.; Sweeny, E.G. Frugal Innovation: Core Competencies to Address Global Sustainability. J. Manag. Glob. Sustain. 2013, 1, 63-82. [CrossRef]

19. Zeschky, M.; Widenmayer, B.; Gassmann, O. Frugal innovation in emerging markets. Res. Technol. Manag. 2011, 54, 38-45. [CrossRef]

20. London, T.; Hart, S.T. Reinventing strategies for emerging markets: Beyond the Transnational Model. J. Int. Bus. Stud. 2004, 35, 350-370. [CrossRef]

21. Tapia-Fonllem, C.; Corral-Verdugo, V.; Fraijo-Sing, B.; Durón-Ramos, M.F. Assessing Sustainable Behavior and its Correlates: A Measure of Pro-Ecological, Frugal, Altruistic and Equitable Actions. Sustainability 2013, 5, 711-723. [CrossRef]

22. Iwata, O. Coping style and three psychological measures associated with environmentally responsible behavior. Soc. Behav. Personal. 2002, 30, 661-669. [CrossRef]

23. Albert, M. Sustainable Frugal Innovation-The connection between frugal innovation and sustainability. J. Clean. Prod. 2019, 237, 117747. [CrossRef]

24. Dunk, A.S. Product innovation, budgetary control, and the financial performance of firms. Br. Account. Rev. 2011, 43, 102-111. [CrossRef]

25. Khan, R. How Frugal Innovation Promotes Social Sustainability. Sustainability 2016, 8, 1034. [CrossRef]

26. Duque Oliva, E.J.; Cervera Taulet, A.; Rodríguez Romero, C. A bibliometric analysis of models measuring the concept of perceived quality inproviding internet service. Innovar Rev. Cienc. Ad. 2006, 16, 223-243.

27. Zupic, I.; Cater, T. Bibliometric Methods in Management and Organization. Organ. Res. Methods 2015, 18, 429-472. [CrossRef]

28. Hallinger, P.; Suriyankietkaew, S. Science Mapping of the Knowledge Base on Sustainable Leadership, 1990-2018. Sustainability 2018, 10, 4846. [CrossRef]

29. Van Raan, A.F.J. The use of bibliometric analysis in research performance assessment and monitoring of interdisciplinary scientific developments. Technol. Assess. Theory. Pract. 2003, 1, 20-29. [CrossRef]

30. Ding, Y.; Rousseau, R.; Wolfram, D. Measuring Scholarly Impact. Methods and Practice; Springer: Cham, Switzerland, 2014.

31. Thanuskodi, S. A bibliometric study. J. Soc. Sci. 2010, 24, 77-80. [CrossRef]

32. Mongeon, P.; Paul-Hus, A. The journal coverage of Web of Science and Scopus: A comparative analysis. Scientometrics 2016, 106, 213-228. [CrossRef]

33. Cunha, M.P.; Rego, A.; Oliveira, P.; Rosado, P.; Habib, N. Product Innovation in Resource-Poor Environments: Three Research Streams. J. Prod. Innov. Manag 2014, 31, 202-210. [CrossRef]

34. Simula, H.; Hossain, M.; Halme, M. Frugal and reverse innovations-Quo Vadis? Curr. Sci. 2015, 109, 1567-1572. [CrossRef]

35. Zeschky, M.; Winterhalter, S.; Gassmann, O. From Cost to Frugal and Reverse Innovation: Mapping the Field and Implications for Global Competitiveness. Res. Tech. Manag. 2014, 57, 20-27.

36. Hartley, J. New development: Eight and a half propositions to stimulate frugal innovation. Public Money Manag. 2014, 34, 227-232. [CrossRef]

37. Van Beers, C.; Knorringa, P.; Leliveld, A. Frugal innovation in Africa: Tracking Unilever's washing-powder sachets. In Transforming Innovations in Africa: Explorative Studies on Appropriation in African Societies; Gewald, J.B., Leliveld, A., Pesa, I., Eds.; Brill: Leiden, The Netherlands, 2012; pp. 59-77.

38. Soni, P.; Krishnan, R.T. Frugal innovation: Aligning theory, practice, and public policy. JIBR 2014, 6, 29-47. [CrossRef]

39. Brem, A.; Wolfram, P. Research and development from the bottom up introduction of terminologies for new product development in emerging markets. J. Innov. Entrep. 2014, 3, 9. [CrossRef]

40. George, G.; McGahan, A.M.; Prabhu, J. Innovation for inclusive growth: Towards a theoretical framework and a research agenda. J. Manag. Stud. 2012, 49, 661-683. [CrossRef] 
41. Kumar, N.; Puranam, P. India Inside: The Emerging Innovation Challenge to the West; Harvard Business Press Books: Cambridge, MA, USA, 2011.

42. Radjou, N.; Prabhu, J.C. Frugal Innovation: How to Do More with Less, 1st ed.; Public Affairs: New York, NY, USA, 2015.

43. Prahalad, C.K.; Mashelkar, R.A. Innovation's holy grail. Harv. Bus. Rev. 2010, 88, 132-141.

44. Petrick, I.J.; Juntiwasarakij, S. The rise of the rest: Hotbeds of innovation in emerging markets. Res. Technol. Manag. 2011, 54, 24-29. [CrossRef]

45. Hossain, M. Frugal innovation: Conception, development, diffusion, and outcome. J. Clean. Prod. 2020, 262, 121456. [CrossRef]

46. Howell, R.; van Beers, C.; Doorn, V. Value capture and value creation: The role of information technology in business models for frugal innovations in Africa. Technol. Forecast. Soc. Chang. 2018, 131, 227-239. [CrossRef]

47. Hossain, M.; Simula, H.; Halme, M. Can frugal go global? Diffusion patterns of frugal innovations. Technol. Soc. 2016, 46, 132-139. [CrossRef]

48. Wan, F.; Williamson, P.J.; Yin, E. Antecedents and implications of disruptive innovation: Evidence from China. Technovation 2015, 39, 94-104. [CrossRef]

49. Pisoni, A.; Michelini, L.; Martignoni, G. Frugal approach to innovation: State of the art and future perspectives. J. Clean. Prod. 2018, 171, 107-126. [CrossRef]

50. Luo, Y.; Child, J. A composition-based view of firm growth. Manag. Organ. Rev 2015, 11, 379-411. [CrossRef]

51. Van de Ven, A.H.; Jing, R. Indigenous management research in China from an engaged scholarship perspective. Manag. Organ. Rev. 2012, 8, 123-137. [CrossRef]

52. Nair, A.; Guldiken, O.; Fainshmidt, S.; Pezeshkan, A. Innovation in India: A review of past research and future directions. Asia Pac. J. Manag. 2015, 32, 925-958. [CrossRef]

53. Altmann, P.; Engberg, R. Frugal Innovation and Knowledge Transferability: Innovation for Emerging Markets Using HomeBased R\&D Western firms aiming to develop products for emerging markets may face knowledge transfer barriers that favor a home-based approach to frugal innovation. Res. Technol. Manag. 2016, 59, 48-55. [CrossRef]

54. Shepherd, D.A.; Parida, V.; Wincent, J. The surprising duality of jugaad: Low firm growth and high inclusive growth. J. Manag. Stud. 2020, 57, 87-128. [CrossRef]

55. Sarkar, S. Grassroots entrepreneurs and social change at the bottom of the pyramid: The role of bricolage. Enterpren. Reg. Dev. 2018, 30, 421-449. [CrossRef]

56. Blismas, N.; Wakefield, R. Engineering sustainable solutions through off-site manufacture. In Technology, Design and Process Innovation in the Built Environment; Newton, P., Hampson, K., Drogemuller, R., Eds.; Spon Press: London, UK, 2009; pp. 355-370.

57. Awais, M.; Samin, T.; Gulzar, M.A.; Hwang, J. The sustainable development of the China Pakistan economic corridor: Synergy among economic, social, and environmental sustainability. Sustainability 2019, 11, 7044. [CrossRef]

58. Strezov, V.; Evans, A.; Evans, T.J. Assessment of the economic, social and environmental dimensions of the indicators for sustainable development. Sustain. Dev. 2017, 25, 242-253. [CrossRef]

59. Eizenberg, E.; Jabareen, Y. Social Sustainability: A New Conceptual Framework. Sustainability 2017, 9, 68. [CrossRef]

60. Bocken, N.M.P.; Short, S.W.; Rana, P.; Evans, S. A literature and practice review to develop sustainable business model archetypes. J. Clean. Prod. 2014, 65, 42-56. [CrossRef]

61. Rosca, E.; Reedy, J.; Bendul, J.C. Does Frugal Innovation enable sustainable development? A systematic literature review. Eur. J. Dev. Res. 2018, 30, 136-157. [CrossRef]

62. Hopwood, B.; Mellor, M.; O’Brien, G. Sustainable development: Mapping different approaches. Sustain. Dev. 2005, 13, 38-52. [CrossRef]

63. Wang, L.; Ma, L.; Wu, K.J.; Chiu, A.S.; Nathaphan, S. Applying fuzzy interpretive structural modeling to evaluate responsible consumption and production under uncertainty. Ind. Manag. Data Syst. 2018, 118, 432-462. [CrossRef]

64. Carter, C.R.; Rogers, D.S. A framework of sustainable supply chain management: Moving toward new theory. Int. J. Phys. Distrib. Logist. Manag. 2008, 38, 360-387. [CrossRef]

65. Elkington, J. Partnerships from cannibals with forks: The triple bottom line of 21st-century business. Environ. Qual. Manag. 1998, 8, 37-51. [CrossRef]

66. Kleindorfer, P.R.; Singhal, K.; Wassenhove, L.V. Sustainable Operations Management. Prod. Oper. Manag. 2005, 14, 482-492. [CrossRef]

67. Høgevold, N.M.; Svensson, G.; Rodriguez, R.; Eriksson, D. Relative importance and priority of TBL elements on the corporate performance. Manag. Environ. Qual. 2019, 30, 609-623. [CrossRef]

68. Rammel, C. Sustainable Development and Innovations: Lessons from the Red Queen. Int. J. Sustain. Dev. 2003, 6, 395-416. [CrossRef]

69. Rennings, K. Redefining innovations-Eco-innovations research and the contribution from ecological economics. Ecol. Econ. 2000, 32, 319-332. [CrossRef]

70. Filho, F.L.; Fritzen, B.; Vargas, V.R.; Paço, A.; Zhang, Q.; Doni, F.; Azul, M.A.; Vasconcelos, R.P.; Ioannis, I.E.; Skouloudis, A.; et al Social innovation for sustainable development: Assessing current trends. Int. J. Sustain. Dev. World Ecol. 2021, 28, 1-12. [CrossRef]

71. Seyfang, G.; Smith, A. Grassroots innovations for sustainable development: Towards a new research and policy agenda. Env. Polit 2007, 16, 584-603. [CrossRef] 
72. Dawson, P.; Daniel, L. Understanding social innovation: A provisional framework. Int. J. Technol. Manag. 2010, 51, 9-21. [CrossRef]

73. Adenle, A.A.; Wedig, K.; Azadi, H. Sustainable agriculture and food security in Africa: The role of innovative technologies and international organizations. Technol. Soc. 2019, 58, 101143. [CrossRef]

74. Omri, A. Technological innovation and sustainable development: Does the stage of development matter? Environ. Impact Assess. Rev. 2020, 83, 106398. [CrossRef]

75. Omri, A. Entrepreneurship, sectoral outputs and environmental improvement: International evidence. Technol. Soc. Chang. 2018, 128, 46-55. [CrossRef]

76. Gunawan, J.; Permatasari, P.; Tilt, C. Sustainable development goal disclosures: Do they support responsible consumption and production? J. Clean. Prod. 2020, 246, 118989. [CrossRef]

77. Dhahri, S.; Omri, A. Entrepreneurship contribution to the three pillars of sustainable development: What does the evidence really say? World Dev. 2018, 106, 64-77. [CrossRef]

78. Sullivan, K.; Thomas, S.; Rosano, M. Using industrial ecology and strategic management concepts to pursue the Sustainable Development Goals. J. Clean. Prod. 2018, 174, 237-246. [CrossRef]

79. De las Heras, A.; Relinque-Medina, F.; Zamora-Polo, F.; Luque-Sendra, A. Analysis of the evolution of the sharing economy towards sustainability. Trends and transformations of the concept. J. Clean. Prod. 2021, 291, 125227. [CrossRef]

80. Dovers, S.R.; Handmer, J.W. Uncertainty, sustainability and change. Glob. Environ. Chang. 1992, 2, 262-276. [CrossRef]

81. Tseng, M.L.; Zhu, Q.; Sarkis, J.; Chiu, A.S. Responsible consumption and production (RCP) in corporate decision-making models using soft computation. Ind. Manag. Data Syst. 2018, 118, 322-329. [CrossRef]

82. Moraru, R.I.; Paun, A.P.; Dura, C.C.; Dinulescu, R.; Potcovaru, A.M. Analysis of the drivers of occupational health and safety performance disclosures by Romanian companies. Econ. Comput. Econ. Cybern. Stud. Res. 2020, 3, $197-214$.

83. Abdelkafi, N.; Täuscher, K. Business models for sustainability from a system dynamics perspective. Organ. Environ. 2016, 29, 74-96. [CrossRef]

84. Iqbal, Q.; Ahmad, N.H. Sustainable development: The colors of sustainable leadership in learning organization. Sustain. Dev. 2020, 29, 108-119. [CrossRef]

85. Zott, C.; Amit, R.; Massa, L. The business model: Recent developments and future research. J. Manag. 2011, 37, $1019-1042$.

86. Geissdoerfer, M.; Morioka, S.N.; De Carvalho, M.M.; Evans, S. Business models and supply chains for the circular economy. J. Clean. Prod. 2018, 190, 712-721. [CrossRef]

87. Nidumolu, R.; Prahalad, C.K.; Rangaswami, M.R. Why sustainability is now the key driver of innovation. IEEE Eng. Manag. Rev. 2013, 87, 56-64. [CrossRef]

88. Neumann, L.; Winterhalter, S.; Gassmann, O. Market maketh magic-consequences and implications of market choice for frugal innovation. Int. J. Technol. Manag. 2020, 83, 55-77. [CrossRef]

89. Hossain, M. Frugal innovation and sustainable business models. Technol. Soc. 2021, 64, 101508. [CrossRef]

90. Ananthram, S.; Chan, C. Institutions and frugal innovation: The case of Jugaad. Asia Pac. J. Manag. 2021, 38, 1031-1060. [CrossRef]

91. Kroll, H.; Gabriel, M. Frugal innovation in, by and for Europe. Int. J. Technol. Manag. 2020, 83, 34-54. [CrossRef]

92. Usama, M.; Ramish, A. Towards a sustainable Reverse Logistics framework/typologies based on Radio Frequency Identification (RFID). Operat. Supply Chain Manag. 2020, 13, 222-232. [CrossRef]

93. Fernando, Y.; Jabbour, C.J.C.; Wah, W.-X. Pursuing green growth in technology firms through the connections between environmental innovation and sustainable business performance: Does service capability matter? Resour. Conserv. Recycl. 2019, 141, 8-20. [CrossRef]

94. Jabbour, C.J.; Sehnem, S.; Mani, V. Pathways towards sustainability in manufacturing organizations: Empirical evidence on the role of green human resource management. Bus. Strategy Env. 2020, 29, 212-228.

95. Altgilbers, N.; Walter, L.; Moehrle, M.G. Frugal invention candidates as antecedents of frugal patents-The role of frugal attributes analysed in the medical engineering technology. Int. J. Innov. Manag. 2020, 24, 2050082. [CrossRef]

96. Inigo, E.A.; Albareda, L. Understanding sustainable innovation as a complex adaptive system: A systemic approach to the firm. J. Clean. Prod. 2016, 126, 1-20. [CrossRef]

97. Kim, B.; Azzaro-Pantel, C.; Pietrzak-David, M.; Maussion, P. Life cycle assessment for a solar energy system based on reuse components for developing countries. J. Clean. Prod. 2019, 208, 1459-1468. [CrossRef]

98. Roscoe, S.; Subramanian, N.; Jabbour, J.C.; Chong, T. Green human resource management and the enablers of green organisational culture: Enhancing a firm's environmental performance for sustainable development. Bus. Strategy Environ. 2019, 28, 737-749. [CrossRef]

99. Kuckertz, A.; Wagner, M. The influence of sustainability orientation on entrepreneurial intentions-Investiganyoting the role of business experience. J. Bus. Ventur. 2010, 25, 524-539. [CrossRef]

100. Dressler, A.; Bucher, J. Introducing a sustainability evaluation framework based on the Sustainable Development Goals applied to four cases of South African frugal innovation. Bus. Strategy Dev. 2018, 1, 276-285. [CrossRef]

101. Wolff, D.; Haudeville, B. How could standardization support the production and diffusion of frugal innovations? J. Innov. Econ. 2016, 21, 27-37.

102. Le Bas, C. Frugal innovation as environnemental innovation. Int. J. Technol. Manag. 2020, 83, 78-96. [CrossRef] 
103. Sharma, A.; Iyer, G.R. Resource-constrained product development: Implications for green marketing and green supply chains. Ind. Mark. Manag. 2012, 41, 599-608. [CrossRef]

104. Hyvärinen, A.; Keskinen, M.; Varis, O. Potential and Pitfalls of Frugal Innovation in the Water Sector: Insights from Tanzania to Global Value Chains. Sustainability 2016, 8, 888. [CrossRef]

105. Wolhart, L.; Bunger, M.; Lang-Koetz, C.; Wagner, F. Corporate and Grassroot Frugal Innovation: A Comparison of Top-Down and Bottom-Up Strategies. Technol. Innov. Manag. Rev. 2016, 6, 5-17.

106. Knorringa, P.; Peša, I.; Leliveld, A.; Van Beers, C. Frugal innovation and development: Aides or adversaries? Eur. J. Dev. Res. 2016, 28, 143-153. [CrossRef]

107. Levänen, J.; Hossain, M.; Lyytinen, T.; Hyvärinen, A.; Numminen, S.; Halme, M. Implications of frugal innovations on sustainable development: Evaluating water and energy innovations. Sustainability 2016, 8, 4. [CrossRef]

108. Posen, H.E.; Keil, T.; Meer, F.D. Renewing research on problemistic search-A review and research agenda. Acad. Manag. Ann. 2018, 12, 208-251. [CrossRef]

109. Hang, C.; Chen, J.; Subramian, A. Developing disruptive products for emerging economies: Lessons from Asian cases. Res. Technol. Manag. 2010, 53, 21-26. [CrossRef]

110. Iqbal, Q.; Hazlina, N.; Zeyun, A.; Li, Y.L. To walk in beauty: Sustainable leadership, frugal innovation and environmental performance. MDE 2020, 7-14. [CrossRef]

111. Iqbal, Q.; Ahmad, N.H.; Halim, H.A. Insights on entrepreneurial bricolage and frugal innovation for sustainable performance. Bus. Strat. Dev. 2021, 4, 237-245. [CrossRef]

112. Iqbal, Q.; Ahmad, N.H.; Li, Z. Frugal-based innovation model for sustainable development: Technological and market turbulence. LODJ 2021, 42, 396-406. [CrossRef]

113. Weyrauch, T.; Herstatt, C. What is frugal innovation? Three defining criteria. J. Frugal Innov. 2017, 2, 1-17. [CrossRef]

114. Von Janda, S.; Kuester, S.; Schuhmacher, M.C.; Shainesh, G. What frugal products are and why they matter: A cross-national multi-method study. J. Clean. Prod. 2020, 246, 118977. [CrossRef]

115. Jha, S.K.; Parulkar, I.; Krishnan, R.T.; Dhanaraj, C. Developing New Products in Emerging Markets. MIT Sloan Management Review. 15 March 2016. Available online: https:/ / sloanreview.mit.edu/article/developing-new-products-in-emerging-markets (accessed on 27 December 2021).

116. Baud, I. Moving towards inclusive development? Recent views on inequalities, frugal innovations, urban geo-technologies, gender and hybrid governance. Eur. J. Dev. Res. 2016, 28, 119-129. [CrossRef]

117. Friedman, M. Capitalism and Freedom; The University of Chicago Press: Chicago, IL, USA, 1962.

118. Schaltegger, S.; Hörisch, J. In search of the dominant rationale in sustainability management: Legitimacy-or profit-seeking? J. Bus. Ethics 2015, 145, 259-276. [CrossRef]

119. Tata, R.N.; Matten, D. Corporate community involvement in the 21st century. In Re-Imagining Capitalism: Towards a Responsible, Long-Term Model; Barton, D., Horvath, M., Kipping, M., Eds.; Oxford University Press: Oxford, UK, 2016 ; pp. 68-83.

120. Nahi, T. Cocreation at the base of the pyramid: Reviewing and organizing the diverse conceptualizations. Organ. Env. 2016, 29, 416-437. [CrossRef]

121. Sachs, J.D. The Age of Sustainable Development; Columbia University Press: New York, NY, USA, 2015.

122. Kristoffersen, E.; Blomsma, F.; Mikalef, P.; Li, J.Y. The smart circular economy: A digital-enabled circular strategies framework for manufacturing companies. J. Bus. Res. 2020, 120, 241-261. [CrossRef]

123. Dey, P.; Malesios, C.; De, D.; Budhwar, P.; Chowdhury, S.; Cheffi, W. Circular Economy to Enhance Sustainability of Small and Medium sized Enterprises. Bus. Strategy Env. 2020, 29, 2145-2169. [CrossRef]

124. Ritter-Hayashi, D.; Knoben, J.; Vermeulen, P.A.M. Success Belongs to the Flexible Firm: How Labor Flexibility Can Retain Firm Innovativeness in Times of Downsizing. 2018. Available online: https://ideas.repec.org/p/tiu/tiutis/749e1bae-6946-40cb-a5fcebc3ee63cd7c.html (accessed on 27 December 2021).

125. Fischer, B.; Guerrero, M.; Guimón, J.; Schaeffer, P.R. Knowledge transfer for frugal innovation: Where do entrepreneurial universities stand? J. Knowl. Manag. 2020, 25, 360-379. [CrossRef]

126. Niroumand, M.; Shahin, A.; Naghsh, A.; Peikari, H.R. Frugal innovation enablers: A comprehensive framework. Int. J. Innov. Sci. 2020, 12, 1-20. [CrossRef]

127. Igwe, P.A.; Odunukan, K.; Rahman, M.; Rugara, D.G.; Ochinanwata, C. How entrepreneurship ecosystem influences the development of frugal innovation and informal entrepreneurship. Thunderbird Int. Bus. Rev. 2020, 62, 475-488. [CrossRef]

128. Agarwal, N.; Brem, A.; Dwivedi, S. Frugal and reverse innovation for harnessing the business potential of emerging markets-The case of a danish mnc. Int. J. Innov. Manag. 2020, 24, 2050009. [CrossRef]

129. Borchardt, M.; Pereira, G.; Ferreira, A.; Soares, M.; Sousa, J.; Bataliga, D. Leveraging frugal innovation in micro-and small enterprises at the base of the pyramid in Brazil: An analysis through the lens of dynamic capabilities. JEEE 2021, 13, 864-886. [CrossRef]

130. Winkler, T.; Ulz, A.; Knöbl, W.; Lercher, H. Frugal innovation in developed markets-Adaption of a criteria-based evaluation model. J. Innov. Knowl. 2020, 5, 251-259. [CrossRef]

131. Wimschneider, C.; Agarwal, N.; Brem, A. Frugal Innovation for the BoP in Brazil-An Analysis and Comparison with Asian Lead Markets. Int. J. Technol. Manag. 2020, 83, 134-159. [CrossRef] 
132. Santos, L.L.; Borini, F.M.; De Miranda, O.; Rossetto, M.; Bernardes, R.C. Bricolage as capability for frugal innovation in emerging markets in times of crisis. Eur. J. Innov. Manag. 2020. [CrossRef]

133. Herstatt, C.; Tiwari, R. Opportunities of Frugality in the Post-Corona Era; Working Paper, No. 110; Hamburg University of Technology (TUHH), Institute for Technology and Innovation Management (TIM): Hamburg, Germany, 2020; Available online: https:/ / www.econstor.eu/handle/10419/220088 (accessed on 27 December 2021).

134. Ploeg, M.; Knoben, J.; Vermeulen, P.; Van Beers, C. Rare gems or mundane practice? Resource constraints as drivers of frugal innovation. Innovation 2021, 23, 93-126. [CrossRef]

135. Bhaduri, S.; Talat, N. RRI Beyond its Comfort Zone: Initiating a Dialogue with Frugal Innovation by 'the Vulnerable'. Sci. Technol. Soc. 2020, 25, 273-290. [CrossRef]

136. Lim, C.; Lee, J.H.; Sonthikorn, P.; Vongbunyong, S. Frugal innovation and leapfrogging innovation approach to the Industry 4.0 challenge for a developing country. Asian J. Technol. Innov. 2021, 29, 87-108. [CrossRef]

137. Pranckute, R. Web of Science (WoS) and Scopus: The Titans of Bibliographic Information in Today's Academic World. Publications 2021, 9, 12. [CrossRef]

138. Vila-Lopez, N.; Küster-Boluda, I. A bibliometric analysis on packaging research: Towards sustainable and healthy packages. Br. Food J. 2021, 123, 684-701. [CrossRef]

139. Leković, M.; Cvijanović, D.; Pantić, N.; Stanišić, T. Evaluative bibliometric analysis of recent trends in rural tourism literature. Ekon. Poljopr. 2020, 67, 1265-1282. [CrossRef]

140. Pătărlăgeanu, S.R.; Dinu, M.; Constantin, M. Bibliometric analysis of the field of green public procurement. Amfiteatru Econ. 2020, 22, 71-81. [CrossRef]

141. Dima, A. The Importance of Innovation in Entrepreneurship for Economic Growth and Development. A Bibliometric Analysis. Rev. Int. Comp. Manag. 2021, 22, 120-131. [CrossRef]

142. Verma, S.; Wolf, P.; Madsen, E.S. A scientometric analysis of fourth-generation KM challenges: A systematic network analysis of last decade (2009-2019). In Proceedings-Knowledge in Digital Age; IFKAD: Matera, Italy, 2020; Available online: https: / / www.ifkad.org/proceedings-ebooks (accessed on 21 November 2021).

143. Ciger, A. Audit Quality: A Bibliometric Analysis (1981-2020). Sci. Ann. Econ. Bus. 2020, 67, 473-494. [CrossRef]

144. Cicea, C.; Marinescu, C. Bibliometric analysis of foreign direct investment and economic growth relationship. A research agenda. J. Bus. Econ. Manag. 2021, 22, 445-466. [CrossRef]

145. Polat, Z.A. Evolution and future trends in global research on cadastre: A bibliometric analysis. GeoJournal 2019, 84, 1121-1134 [CrossRef]

146. Lei, T.T.; Qin, Y.; Xu, Z.S.; Borzooei, R.A. A bibliometric analysis of Iranian Journal of Fuzzy Systems (2007-2020). Iran J. Fuzzy Syst. 2021, 18, 1-17.

147. Koseoglu, M.A.; Rahimi, R.; Okumus, F.; Liu, J. Bibliometric studies in tourism. Ann. Tourism Res. 2016, 61, 180-198. [CrossRef]

148. Forés, B.; Breithaupt Janssen, Z.; Takashi Kato, H. A Bibliometric Overview of Tourism Family Business. Sustainability 2021, 13, 12822. [CrossRef]

149. Zamora-Polo, F.; Sanchez-Martin, J. Teaching for a Better World. Sustainability and Sustainable Development Goals in the Construction of a Change-Maker University. Sustainability 2019, 11, 4224. [CrossRef]

150. Paul, J.; Lim, W.M.; O'Cass, A.; Hao, A.W.; Bresciani, S. Scientific procedures and rationales for systematic literature reviews (SPAR-4-SLR). Int. J. Consum. Stud. 2021, 45, 1-16. [CrossRef]

151. Moher, D.; Shamseer, L.; Clarke, M.; Ghersi, D.; Liberati, A.; Petticrew, M.; Shekelle, P.; Stewart, L.A.; PRISMA-P Group. Preferred reporting items for systematic review and meta-analysis protocols (PRISMA-P) 2015 statement. Syst. Rev. 2015, 4, 1. [CrossRef]

152. Zhang, J.Z.; Srivastava, P.R.; Sharma, D.; Eachempati, P. Big data analytics and machine learning: A retrospective overview and bibliometric analysis. Expert Syst. Appl. 2021, 184, 115561. [CrossRef]

153. Donthu, N.; Kumar, S.; Mukherjee, D.; Pandey, N.; Lim, W.M. How to conduct a bibliometric analysis: An overview and guidelines. J. Bus. Res. 2021, 133, 285-296. [CrossRef]

154. Donthu, N.; Kumar, S.; Pandey, N.; Gupta, P. Forty years of the International Journal of Information Management: A bibliometric analysis. Int. J. Inform. Manag. 2021, 57, 102307. [CrossRef]

155. Abad-Segura, E.; González-Zamar, M.D.; Belmonte-Ureña, L.J. Effects of circular economy policies on the environment and sustainable growth: Worldwide research. Sustainability 2020, 12, 5792. [CrossRef]

156. Williams Jr, R.I.; Clark, L.A.; Clark, W.R.; Raffo, D.M. Re-examining systematic literature review in management research: Additional benefits and execution protocols. Eur. Manag. J. 2021, 39, 521-533. [CrossRef]

157. Hensel, P.G. Reproducibility and replicability crisis: How management compares to psychology and economics-A systematic review of literature. Eur. Manag. J. 2021, 39, 577-594. [CrossRef]

158. Birkle, C.; Pendlebury, D.A.; Schnell, J.; Adams, J. Web of Science as a data source for research on scientific and scholarly activity. Quant. Sci. Stud. 2020, 1, 363-376. [CrossRef]

159. Ng, C.K.; Wu, C.H.; Yung, K.L.; Ip, W.H.; Cheung, T. A semantic similarity analysis of Internet of Things. Enterp. Inform. Syst. 2018, 12, 820-855. [CrossRef]

160. Van Eck, N.J.; Waltman, L. Software survey: VOSviewer, a computer program for bibliometric mapping. Scientometrics 2010, 84, 523-538. [CrossRef] 
161. Moral Muñoz, J.A.; Herrera Viedma, E.; Santisteban Espejo, A.; Cobo, M.J. Software tools for conducting bibliometric analysis in science: An up-to-date review. Prof. Inf. 2020, 29, e290103. [CrossRef]

162. Paul, J.; Criado, A.R. The art of writing literature review: What do we know and what do we need to know? Int. Bus. Rev. 2020, 29, 101717. [CrossRef] 